\title{
Speleothem Paleoclimatology for the Caribbean, Central America, and North America
}

\author{
Jessica L. Oster ${ }^{1, *(\mathbb{D}}$, Sophie F. Warken ${ }^{2,3} \mathbb{D}$, Natasha Sekhon ${ }^{4}$, Monica M. Arienzo ${ }^{5}$ (D) and \\ Matthew Lachniet ${ }^{6}$ (iD) \\ 1 Department of Earth and Environmental Sciences, Vanderbilt University, Nashville, TN 37240, USA \\ 2 Department of Geosciences, University of Heidelberg, 69120 Heidelberg, Germany; \\ swarken@iup.uni-heidelberg.de \\ 3 Institute of Environmental Physics, University of Heidelberg, 69120 Heidelberg, Germany \\ 4 Department of Geological Sciences, Jackson School of Geosciences, University of Texas, \\ Austin, TX 78712, USA; nsekhon@utexas.edu \\ 5 Desert Research Institute, Reno, NV 89512, USA; Monica.arienzo@dri.edu \\ 6 Department of Geoscience, University of Nevada, Las Vegas, NV 89154, USA; matthew.lachniet@unlv.edu \\ * Correspondence: jessica.l.oster@vanderbilt.edu
}

Received: 27 December 2018; Accepted: 21 January 2019; Published: 28 January 2019

check for updates

\begin{abstract}
Speleothem oxygen isotope records from the Caribbean, Central, and North America reveal climatic controls that include orbital variation, deglacial forcing related to ocean circulation and ice sheet retreat, and the influence of local and remote sea surface temperature variations. Here, we review these records and the global climate teleconnections they suggest following the recent publication of the Speleothem Isotopes Synthesis and Analysis (SISAL) database. We find that low-latitude records generally reflect changes in precipitation, whereas higher latitude records are sensitive to temperature and moisture source variability. Tropical records suggest precipitation variability is forced by orbital precession and North Atlantic Ocean circulation driven changes in atmospheric convection on long timescales, and tropical sea surface temperature variations on short timescales. On millennial timescales, precipitation seasonality in southwestern North America is related to North Atlantic climate variability. Great Basin speleothem records are closely linked with changes in Northern Hemisphere summer insolation. Although speleothems have revealed these critical global climate teleconnections, the paucity of continuous records precludes our ability to investigate climate drivers from the whole of Central and North America for the Pleistocene through modern. This underscores the need to improve spatial and temporal coverage of speleothem records across this climatically variable region.
\end{abstract}

Keywords: SISAL database; speleothem; cave; oxygen isotopes; North America; Central America; Caribbean

\section{Introduction}

Speleothems, or secondary cave carbonates, have become essential tools for the reconstruction of past terrestrial climate variability [1]. Speleothem oxygen isotope records (hereafter $\delta^{18} \mathrm{O}_{\text {spel }}$ ) in particular have provided important information about changes in precipitation, temperature, and atmospheric circulation over low and middle latitude regions throughout the world. The Speleothem Isotopes Synthesis and Analysis (SISAL) project and database aims to compile published speleothem data globally to facilitate paleoclimate reconstructions and the evaluation of climate models [1]. The first version of the database (SISAL_v1) contains 376 speleothem records [2]. These records were compiled from public archives and published data or provided through correspondence with the 
original authors. The challenges found while compiling such data are discussed in [1]. The database archives speleothem oxygen and carbon isotope data, detailed chronologic and analytical information, and important metadata for each cave site and speleothem such as bedrock geology, overburden thickness, and whether cave monitoring was conducted, among other pieces of information that are essential for working with and interpreting speleothem isotope records.

Of the 376 records included in SISAL_v1, 42 are from cave sites in Central and North America and the Caribbean [2]. These records cover a vast region, spanning the tropics to mid-latitudes and bordering two oceans, with climate controls that are highly variable both in the modern and through time. Speleothem records from this region have revealed critical climate teleconnections between the polar regions, the tropics, and the mid-latitudes at decadal to orbital timescales [3-6]. These records have provided evidence for the effects of climate variability on ancient civilizations [7-9], and contributed toward open questions and key debates regarding Earth's climate system [3,10]. Here, we discuss the spatial and temporal coverage of North and Central American and Caribbean speleothem records included in SISAL_v1 and the predominant controls on $\delta^{18} \mathrm{O}_{\text {spel }}$ variability in each region. We review the most salient discoveries arising from regional records included in SISAL_v1 and conduct a statistical analysis to underscore observed spatial relationships. Our summary highlights the value, the challenges, and the opportunities afforded by the SISAL compilation of Central and North American and Caribbean speleothem records.

\section{Study Region and Climate}

The speleothem records included in SISAL_v1 span the low-latitude tropics from Panama through the northern United States (Figure 1), and cover paleoclimatic changes on decadal to orbital scales. Soluble bedrock, including carbonates and evaporites, is present throughout the study region (Figure 1), with extensive and laterally continuous carbonate deposits stretching across large portions of eastern North and Central America, and smaller, tectonically divided deposits of carbonates and evaporites located to the west. For the purpose of this paper, we define Central America as the region stretching from the southern border of Panama to the southern border of Mexico, and North America from Mexico northward. As most of Mexico, including the Yucatan Peninsula, is primarily in the zone of tropical influence, monsoon- and ITCZ- related convection, and easterly wind sources, we group records from there together with the other tropical records from Central America and the Caribbean. We also include the islands in the Caribbean Sea in our discussion of Central American speleothem records, so this region effectively encompasses the area from approximately 7 to $32{ }^{\circ} \mathrm{N}$ and -60 to $-118^{\circ} \mathrm{E}$. We group the records from North America that are strongly influenced by westerly wind sources into the North America section, spanning the Southwestern United States northward to the Arctic Ocean. Given the variable climate and controls on the $\delta^{18} \mathrm{O}$ of precipitation $\left(\delta^{18} \mathrm{O}_{\mathrm{p}}\right)$ across this broad region, we have divided our discussion to focus on three sub-regions: western North America $\left(>32{ }^{\circ} \mathrm{N},<-94^{\circ} \mathrm{E}\right.$, from Texas westward), eastern North America $\left(>30^{\circ} \mathrm{N},>-94^{\circ} \mathrm{E}\right.$, effectively the eastern United States, excluding Florida), and the tropical and subtropical regions of Central American and the Caribbean, including Florida (essentially $<30^{\circ} \mathrm{N}$ ). 


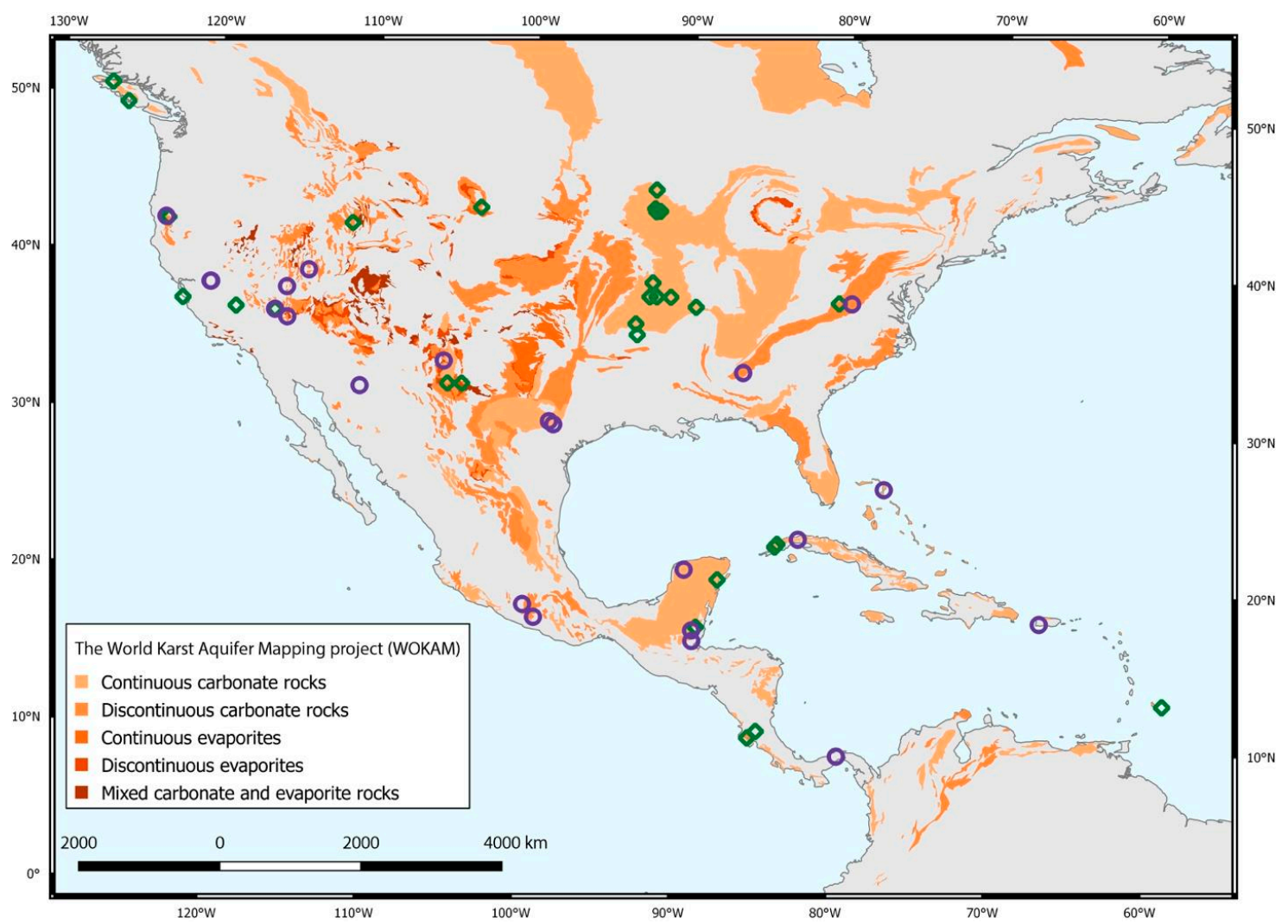

Figure 1. Map showing distribution of carbonate and evaporite rocks in North and Central America provided by the World Karst Aquifer Mapping project (WOKAM [11]). Purple circles indicate speleothem record sites included in SISAL_v1 [1], while green circles indicate speleothem records sites that have been identified, but are not included in SISAL_v1. Specific information about all sites is included in Table 1.

\subsection{Climate and Controls on $\delta^{18} O_{p}$ in Western North America}

\subsubsection{Climate of Western North America}

The climate of western North America is dominated by westerly moisture sources originating from the Pacific Ocean. Precipitation is strongly related to the passage of winter cyclones, which can bring abundant precipitation to the region. The local climate is influenced by the complex topography that generates large gradients in precipitation and temperature [12]. With the exception of the north Pacific coast, much of western North America can be characterized as arid or semi-arid, with orographic rainout occurring first over the coast ranges, Cascade Range, and the Sierra Nevada and the climate becoming progressively more arid moving inland [13]. The entire region is also sensitive to droughts influenced by ocean-atmosphere interactions in the tropical Pacific and tropical North Atlantic [14,15]. Much of western North America receives precipitation that is advected zonally over the continent from the north and central Pacific by winter cyclones that originate in the region south of the Aleutian Low and are transported by the westerly winter storm track [16] (Figure 2A). Moisture from these winter cyclones can penetrate deeply into western North America, providing the dominant source of precipitation and groundwater recharge from the west coast into the Great Basin [17], and reaching as far east as central Texas [18]. However, the most intense rainfall and flooding events along the west coast are often linked to extra-tropical cyclones that derive moisture directly from the central or eastern tropical Pacific. These systems can develop narrow, concentrated corridors of near-surface water vapor known as atmospheric rivers (ARs) which are responsible for the warmest and wettest storms reaching the west coast [19-21] (Figure 2A). A study of extreme precipitation events associated with ARs along the California coast suggests they primarily occur during the negative phase of the Arctic Oscillation 
when the jet stream has a more meridional configuration [22]. Similar work has linked AR frequency and intensity to the occurrence and type of El Niño event [23]. These findings hint at the importance of both high and low latitude teleconnections in driving AR occurrence.

The southwestern portion of North America into northern Central America is also influenced by precipitation associated with the North American Monsoon (NAM). Heating of the Mojave and Sonoran deserts in the summer creates a thermal low that draws moisture from the Gulf of California, Gulf of Mexico, and Caribbean Sea into parts of the southwestern United States and northern Mexico [24]. Most NAM precipitation occurs as isolated thunderstorms or mesoscale convective systems, and thus its influence on modern regional precipitation and its past variability are complex [25]. The dominant moisture source for monsoon rains varies from west to east, with the Gulf of California and the Pacific providing more moisture to the Mojave and Sonoran deserts and the Gulf of Mexico and Caribbean becoming more important toward the east. The Great Plains low level jet also carries moisture through eastern Mexico, influencing precipitation in central and northern Mexico, Texas, and into the Great Plains $[25,26]$.

Large-scale ocean-atmosphere interactions strongly influence patterns of precipitation variability in western North America on interannual to decadal timescales. Historical records of precipitation variability suggest a dipole pattern between the Pacific Northwest and desert southwest displaying opposing relationships with indices of the El Niño/Southern Oscillation (ENSO) [13,27]. The Pacific Decadal Oscillation (PDO) is thought to modulate this relationship on decadal timescales, including control on the shape and location of the transitional zone between the sign of correlation between precipitation and ENSO indices [27]. The strength of the ENSO/precipitation relationship also appears to be modulated by the Atlantic Multidecadal Oscillation (AMO) [27], which also influences summer precipitation over Texas and the southern Great Plains [28].

\subsubsection{Controls on $\delta^{18} \mathrm{O}_{\mathrm{p}}$ and $\delta^{18} \mathrm{O}_{\text {spel }}$}

Long-term analyses of precipitation in western North America showed strong influences of moisture source and temperature on precipitation $\delta^{18} \mathrm{O}$ values $\left(\delta^{18} \mathrm{O}_{\mathrm{p}}\right)$ [29]. Seasonal variations in $\delta^{18} \mathrm{O}_{\mathrm{p}}$ have been observed along the west coast of North America, with summer rain displaying higher isotope ratios and winter rain displaying lower isotope ratios [30-32]. The range of this seasonal signal is small along the coast and becomes magnified inland [30].

Analyses of rain and snow isotopes along the coast from central to southern California indicate that moisture source plays an important role in determining precipitation isotopic ratios with subtropical and tropical Pacific sourced moisture leading to precipitation with higher isotope ratios and mid-latitude and north Pacific sourced moisture leading to lower isotope ratios [17,33]. However, McCabe-Glynn et al., (2016) found no clear isotopic signature associated with ARs, which are often derived from southwesterly moisture plumes reaching the California coast, in an analysis of extreme rainfall events between 2001 and 2011 [22]. Furthermore, isotope-enabled modeling of precipitation isotope signals along the west coast of North America suggests that variations in droplet condensation height due to seasonal changes in the polar jet are the primary driver of the observed seasonal signal in precipitation isotope ratios [34,35]. Observations and models suggest complex controls on the isotopic signal of precipitation in the winter-precipitation dominated region of western North America, and further work is necessary to understand which controls are most important for driving the variations that are transmitted to cave drip waters and ultimately preserved in speleothems.

Moving inland into southwestern North America, the balance of precipitation from isotopically distinct winter westerly and summer monsoonal precipitation sources becomes a more important control on $\delta^{18} \mathrm{O}_{\mathrm{p}}$ [36]. In New Mexico and Arizona, precipitation $\delta^{18} \mathrm{O}$ values are also strongly linked to moisture source [36,37], and in that region summer monsoon rainfall is of high enough amount to infiltrate into aquifers. For example, in Carlsbad Caverns, New Mexico, drip water $\delta^{18} \mathrm{O}$ values of around $-7.9 \%$ VSMOW indicate a mixed summer and winter signal of infiltration [38]. However, isotopic signatures in spring waters and cave drip waters from the Great Basin suggest that the brevity 
of summer precipitation events, coupled with intense evaporation, limits infiltration of monsoon rains [39], indicating that infiltration derived from winter storms is presently the primary source of speleothem growth and suggesting a winter bias for speleothem records [5,40]. In central Texas, assessment of $\delta^{18} \mathrm{O}_{\mathrm{p}}$ determined that precipitation amount (the amount effect) is an important control on $\delta^{18} \mathrm{O}_{\mathrm{p}}$ values during the summer but not the winter and documents that the lowest $\delta^{18} \mathrm{O}_{\mathrm{p}}$ values are associated with tropical cyclones [41].

This regional variability in the climatic controls on $\delta^{18} \mathrm{O}_{\mathrm{p}}$ influences the dominant controls on $\delta^{18} \mathrm{O}_{\text {spel }}$ and as such different aspects of climate variability can be recovered in different locations. Speleothem oxygen isotope records that are most proximal to the Pacific coast are interpreted to respond to changes in surface air temperature that influence $\delta^{18} \mathrm{O}_{\mathrm{p}}$ [42] with some influence by changes in moisture source between more North Pacific and subtropical AR sources [43-45]. A modern (last 1200 years) record of $\delta^{18} \mathrm{O}_{\text {spel }}$ from the southern Sierra Nevada mountains that is not included in SISAL_v1 is interpreted to reflect changes in moisture source that are ultimately driven by northwestern Pacific sea surface temperature changes that influence storm track trajectories [46]. The importance of moisture source versus temperature as a control on $\delta^{18} \mathrm{O}_{\text {spel }}$ near the Pacific coast likely varies depending on the temporal resolution of the speleothem, with higher resolution records more capable of capturing short term shifts in dominant moisture source.

Further inland, $\delta^{18} \mathrm{O}_{\text {spel }}$ from caves in the Great Basin are interpreted to reflect a combination of changes in temperature and moisture source of winter storm systems that are closely aligned with northern hemisphere summer insolation on orbital timescales $[47,48]$. In southwestern North America, speleothem records from Arizona and New Mexico are interpreted to reflect the balance of contribution of winter (relatively depleted in ${ }^{18} \mathrm{O}$ ) versus summer (relatively enriched in ${ }^{18} \mathrm{O}$ ) precipitation, with variations mainly attributed to changing inputs of winter precipitation from the Pacific $[5,40]$. In central Texas, $\delta^{18} \mathrm{O}_{\text {spel }}$ variations were interpreted to be closely tied to the $\delta^{18} \mathrm{O}$ signature of the Gulf of Mexico, which is the primary moisture source region [18].

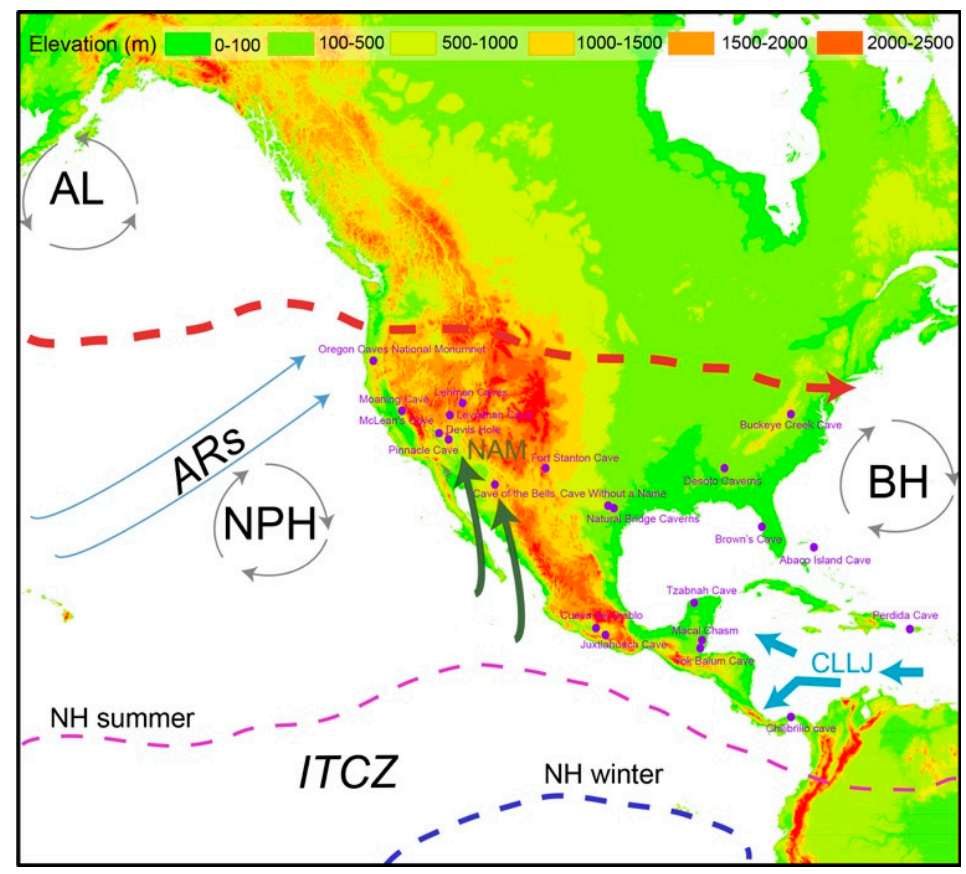

(A)

Figure 2. Cont. 


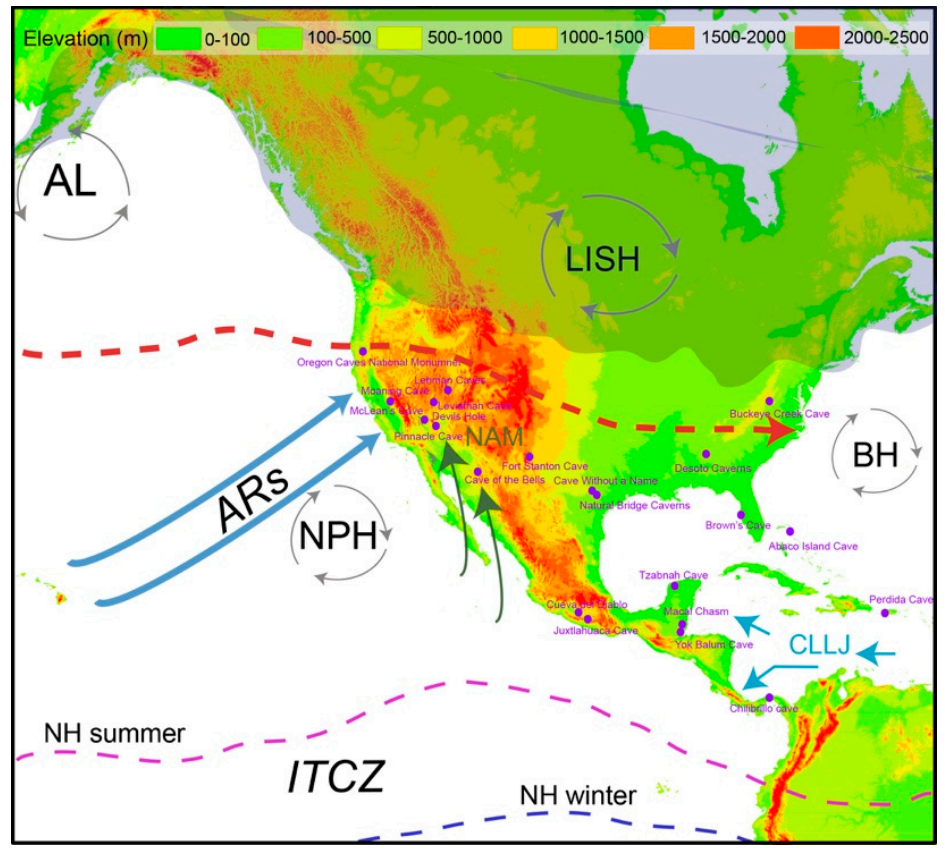

(B)

Figure 2. Conceptual model of components of the climate system for modern (A) and last glacial maximum (B) conditions in North and Central America. Climate models and paleoclimate records indicate that the LGM was characterized by a stronger Aleutian low (AL), weaker North Pacific high (NPH) [49]; high pressure over the Laurentide ice sheet (LISH) and a tilted westerly storm track (red dashed line) [4]; more frequent atmospheric river storms along the west coast of North America (ARs) [49]; a weaker North American monsoon (NAM) [50]; weaker Bermuda high (BH) [51] and Caribbean low level jet [52]; and small southward $\left(<1^{\circ}\right)$ shifts in ITCZ position [53].

\subsection{Climate and Controls on $\delta^{18} O_{p}$ in Eastern North America}

\subsubsection{Climate of Eastern North America}

The climate of Eastern North America reflects the confluence of multiple atmospheric processes, primarily driven by the westerlies, Arctic, Gulf of Mexico, and Atlantic sources. The westerlies transport Pacific or western North American air masses across the continent. The relative influence of these atmospheric sources is in part dictated by the topography of Eastern North America, with the Great Plains area located to the east of the Rockies. The Great Plains is characterized by small mountains to the north, semi-arid climate in the western portion, and increasing humidity to the east [54]. Further east, the topographic high of the Appalachian Mountains and low of the coastal piedmont regions are characterized by humid summers and winter snowfall in higher altitudes and northern latitudes.

During the summer months, the hydroclimate of the eastern North America is dominated by moisture from the Gulf of Mexico and the subtropical Atlantic [55-57]. Transport of lower latitude moisture to continental North America varies with the location and strength of low pressure systems, with steeper pressure gradients resulting in the increased transport of moisture inland [56]. Winter precipitation occurs when warm air masses from subtropical Atlantic and Gulf of Mexico sources interact with cold air masses from the Pacific and Arctic to produce storms that travel eastward with the polar jet stream [55]. Winter frontal storms limit the propagation of warm air masses laden with Gulf of Mexico and Atlantic moisture, which are only occasionally able to penetrate to the interior of the continent [56].

The most intense rainfall and flooding events along the eastern North America are often linked to hurricanes that derive moisture directly from the tropical Atlantic. These storms gain in intensity 
across the Western Atlantic and Caribbean and typically move northward along the east coast, or west into the Gulf of Mexico and into the eastern interior of North America, bringing large quantities of rainfall over short periods of time. Localized "lake effect" precipitation, caused by vertical fluxes of heat and recycled moisture from the lake surface, also occurs adjacent to the Great Lakes [58,59].

\subsubsection{Controls on $\delta^{18} \mathrm{O}_{\mathrm{p}}$ and $\delta^{18} \mathrm{O}_{\text {spel }}$}

Observations of seasonal variations in $\delta^{18} \mathrm{O}_{\mathrm{p}}$ values reflect temperature and source variations with lower values in fall and winter and higher values in the spring and summer [60-63]. In the winter, greater spatial variability in $\delta^{18} \mathrm{O}_{\mathrm{p}}$ values are observed across Eastern North America because of the greater temperature contrasts in the source areas [62]. The Gulf of Mexico is an isotopically enriched source when compared to the more depleted Pacific moisture source.

In addition to seasonal and source variations, geographic variations also influence $\delta^{18} \mathrm{O}_{\mathrm{p}}$ values. Eastern North America $\delta^{18} \mathrm{O}_{\mathrm{p}}$ values are influenced by the Appalachian Mountains and the broad coastal plain bordering the Atlantic Ocean and Gulf of Mexico. The Appalachian Mountains can impart an orographic effect on the $\delta^{18} \mathrm{O}_{\mathrm{p}}$ values. Local influences of Great Lakes lake effect precipitation events can show depleted $\delta^{18} \mathrm{O}_{\mathrm{p}}$ values downwind of the lakes [56,57] due to the depleted signature of the Great Lakes. On sub-seasonal timescales, extratropical cyclones $\delta^{18} \mathrm{O}_{\mathrm{p}}$ values have been shown to be very depleted [64-66]. On longer timescales, $\delta^{18} \mathrm{O}_{\mathrm{p}}$ values may also be influenced by the AMO, however the mechanism is not well understood [63].

In eastern North America, $\delta^{18} \mathrm{O}_{\text {spel }}$ is interpreted to reflect the seasonal balance of precipitation between summer precipitation sourced from the Gulf of Mexico, and winter precipitation from various sources that are more depleted in ${ }^{18} \mathrm{O}$ [55]. In West Virginia, this summer/winter moisture balance is related to strength of the Bermuda High and its ability to advect summer moisture from the Gulf of Mexico $[67,68]$. The combination of speleothem $\delta^{18} \mathrm{O}$ with $\delta^{13} \mathrm{C}$ can help to distinguish between periods of shifts in moisture balance and periods of strong seasonal drought [55].

\subsection{Climate and Controls on $\delta^{18} O_{p}$ in Central America and the Caribbean}

\subsubsection{Climate of Central America and the Caribbean}

The climate of Central America and the Caribbean is influenced by the competing effects of Atlantic and Pacific teleconnection patterns. This region includes continental territories, island chains, and mountain ranges of different orientations and elevations, and interactions between this diverse topography and the large-scale circulation produce sub-regional variations in annual rain totals, length of the rainy season and timing of rainfall maxima [69,70]. The Inter-Tropical Convergence Zone (ITCZ) is the fundamental controlling element of both the Atlantic and the eastern Pacific realms [71,72], and it is the dominant source of rainfall in Central America, particularly south of Guatemala. The meridional oscillation of the ITCZ responds to the seasonal insolation cycle, migrating north during the boreal summer and south during the boreal winter [73,74] (Figure 2A). This seasonal migration produces strong precipitation seasonality in most of Central America, with a pronounced dry season between December and April. As a consequence, the climate of most of Central America can broadly be classified as dry-winter tropical climate, with comparably small seasonal temperature variations. The rainy season occurs as easterly trade winds produced by the North Atlantic subtropical high (NASH) transport moisture from the Atlantic into the Caribbean Sea, where the flow intensifies, forming the Caribbean low level jet (CLLJ) [75,76] (Figure 2A). During boreal summer in the western Caribbean, the CLLJ splits into two branches, with one branch turning northward and transporting moisture to the western Gulf of Mexico, and the southerly branch of the CLLJ continuing westward carrying moisture across the Central American isthmus to the Pacific. During boreal winter, the NASH dominates the Intra-American Sea, and moisture transport is shifted south of the Yucatan Peninsula [77]. Precipitation on the Caribbean and Gulf of Mexico coasts typically is less seasonal, as easterly trade winds during the winter interact with the mountainous topography to produce 
orographic rainfall [78]. On the Pacific slope of southern Mexico, precipitation is advected from the ITCZ, where it is then available for convective systems to produce rainfall in the semi-arid regions of southwestern Mexico.

Besides the ITCZ and the NASH, other significant synoptic influences include the intrusions of polar fronts of midlatitude origin modifying the dry winter and early summer climates of the northern Caribbean and north Central America as well as westward propagating tropical disturbances-a summer season feature associated with enhanced rainfall over the Caribbean [70]. ENSO also influences the climate of Central America, manifesting as a zonal seesaw in sea level pressure (SLP) between the eastern equatorial Pacific and Atlantic Ocean [69]. Hence, in western and southwestern Mexico and the Pacific coast of Central America, changes in precipitation are commonly linked to ENSO variability, with weaker convective precipitation occurring during warm El Niño events, and more convection associated with La Niña conditions [79]. Gulf of Mexico and Caribbean slopes commonly experience an anti-phased ENSO response to the Pacific sectors [69].

\subsubsection{Controls on $\delta^{18} \mathrm{O}_{\mathrm{p}}$ and $\delta^{18} \mathrm{O}_{\text {spel }}$}

The dominant control on the $\delta^{18} \mathrm{O}$ and $\delta^{2} \mathrm{H}$ of Central America precipitation is the progressive depletion of heavy ${ }^{18} \mathrm{O}$ and ${ }^{2} \mathrm{H}$ isotopes in air masses as they undergo rainout. Gradients in $\delta^{18} \mathrm{O}_{\mathrm{p}}$ over Central America are characterized by highest values along the Caribbean and Gulf of Mexico coasts, lowest values near or west of the isthmian divide, and slightly increasing $\delta^{18} \mathrm{O}_{\mathrm{p}}$ values towards the Pacific slope [80-82]. The decrease in $\delta^{18} \mathrm{O}$ values with distance inland reflects the Rayleigh distillation of air masses, with a smaller contribution of Pacific-sourced moisture on the Pacific slope. Superimposed upon the spatial differences are changes in the seasonal variation in $\delta^{18} \mathrm{O}_{\mathrm{p}}$, which is inversely correlated with rainfall amount. The influence of the amount effect on $\delta^{18} \mathrm{O}_{p}$ in Central America and the Caribbean has been observed by studies from e.g., Panama [83], Belize, Guatemala and Mexico [80], Barbados [84], Puerto Rico [85,86], and the Yucatan peninsula [87,88]. However, moisture source and air mass rainout history are also important controls on the isotope values of Central American precipitation [89].

In southern Central America, remote teleconnections to ocean-atmosphere interactions also influence $\delta^{18} \mathrm{O}_{\mathrm{p}}$. For example, $\delta^{18} \mathrm{O}_{\mathrm{p}}$ values on the Pacific coast are related to ENSO forcing: precipitation during warm El Niño events has higher $\delta^{18} \mathrm{O}$ values than during cool La Niña events [83]. This response has been attributed to the increased intensity of convection of storms within the ITCZ during La Niña events, and suggests that speleothems from this region may also be recording past ENSO variability.

Both atmospheric general circulation models (AGCMs) and observational data indicate that the $\delta^{18} \mathrm{O}_{\mathrm{p}}$ signal over the tropical Americas has an annual mean value of around $-3 \%$ VSMOW. In the midlatitudes, seasonal variations in $\delta^{18} \mathrm{O}_{\mathrm{p}}$ can be explained by temperature control on $\delta^{18} \mathrm{O}_{\mathrm{p}}[90]$. Towards lower latitudes, seasonal variations in $\delta^{18} \mathrm{O}_{\mathrm{p}}$ are clearly controlled by precipitation amount, with depleted values occur during the rainy season (JJA in the north). This latitudinal gradient in the dominant controls on $\delta^{18} \mathrm{O}_{\mathrm{p}}$ translates to the interpretations of $\delta^{18} \mathrm{O}_{\text {spel }}$, which are supported by observations of cave drip water, e.g., [86] and multi-proxy speleothem studies, e.g., [8]. In the Bahamas, evidence from stalagmites and fluid inclusions support temperature as the primary control on $\delta^{18} \mathrm{O}_{\text {spel }}$ on millennial timescales [91,92]. However, on the Yucatan Peninsula, cave monitoring suggests that drip water and speleothem $\delta^{18} \mathrm{O}$ closely reflect rainfall amounts $[8,87,88,93]$. Furthermore, it is possible to discern the isotopic signature of individual tropical cyclones in a very high resolution $\delta^{18} \mathrm{O}_{\text {spel }}$ record from Belize that is not included in SISAL_v1 [94]. In Costa Rica, $\delta^{18} \mathrm{O}_{\text {spel }}$ is also interpreted to reflect changes in rainfall amount on millennial to orbital timescales that are associated with changes in sea surface temperatures in the tropical North Atlantic and the intensity or position of the ITCZ [95]. 


\section{North and Central American Speleothem Records in SISAL_v1}

\subsection{Spatial and Temporal Coverage and Regional Potential}

There are 81 published speleothem stable isotope records from Northern and Central America and the Caribbean. Of these, 42 individual records from 22 caves are included in SISAL_v1 [2] (Figure 1, Table 1). The sites represented in SISAL_v1 include 14 from the contiguous United States, 3 from Mexico, 2 from Belize, and 1 each from Panama, the Puerto Rico, and the Bahamas. Coverage across North America in SISAL_v1 is focused in the west (11 sites), with only three sites from the eastern part of the continent. The speleothem records cover a large range in elevation, with multiple submerged caves from the Caribbean region and four caves with elevations $>2,000 \mathrm{~m}$. Comparisons to carbonate lithologies demonstrate several regions that are underrepresented in SISAL_v1, particularly for central/eastern North America (Figure 1). Identified sites not included in SISAL_v1 would improve coverage in the west up to British Columbia, Canada and greatly enhance representation in the midwestern United States. In Central America, identified records would improve representation outside of Mexico (e.g., Belize, Costa Rica) and in the Caribbean (e.g., Cuba, Barbados).

The Central and North American speleothems show variable levels of dating precision, typically with highest precision dates in high uranium aragonites (e.g., Juxtlahuaca Cave, [9]) and high uranium calcites (e.g., Fort Stanton, New Mexico [5]). In some cases, generation of precise age models is hampered by dating inversions and large age uncertainties whereas in others the age precision is suitable for decadal-scale climate analysis. As a result, the archived time series have varying levels of uncertainty.

Temporal coverage of speleothem records in SISAL_v1 extends from 0 - 204 ka BP (all ages are present relative to 1950) (Figure 3a) (Table 1). Coverage is densest over the last $50 \mathrm{ka}$. The representation of speleothem records from different regions across Central and North America varies greatly. High resolution records covering the last 2000 years are primarily from the tropics, and include speleothems from Panama, Puerto Rico, Belize, and Mexico (Figure 3b). However, coverage of the last 2000 years is also provided by records from Oregon and at lower temporal resolution in speleothems from Nevada in western North America and West Virginia in eastern North America. The early to middle Holocene is represented across North America with records from Oregon, Nevada, Texas, Alabama, West Virginia, and Florida as well as southern Mexico. The Last Glacial Maximum (LGM) and deglaciation (10 to $22 \mathrm{ka}$ ) are best represented in records from western North America, but the interval is also covered in records from the Bahamas and southern Mexico. Records older than the LGM are almost exclusively found in western North America, with the exception of a Marine Isotope Stage 3 (MIS3) record from the Bahamas and an MIS5 record from West Virginia. The Devils Hole vein calcites [96] provide the longest calcite $\delta^{18} \mathrm{O}$ record in North and Central America. 

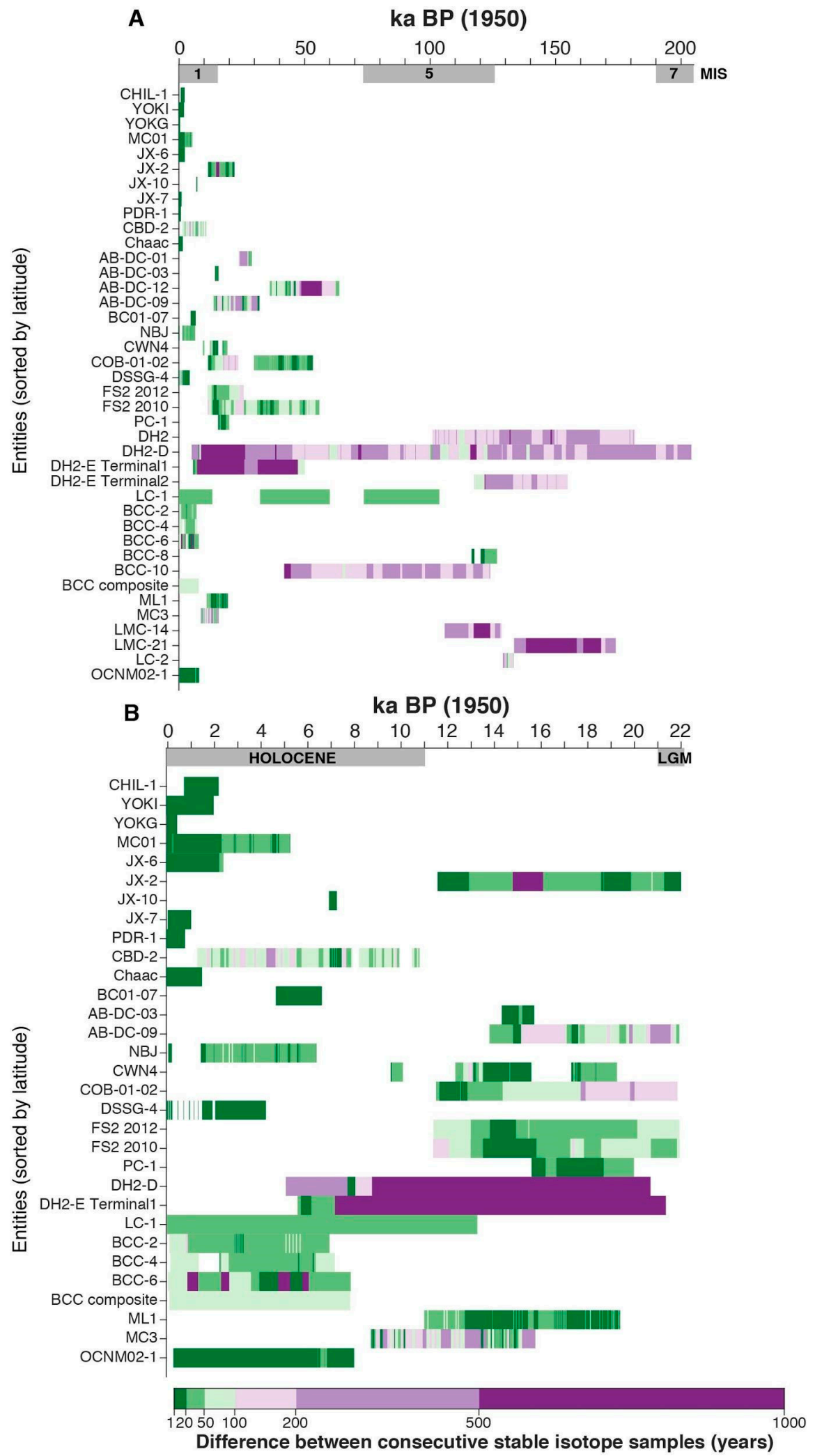

Figure 3. Temporal coverage of North and Central American speleothem records represented in SISAL_v1 for all records (A) and covering only the last $22 \mathrm{ka}(\mathbf{B})$. Shading denotes temporal resolution within records given as the time difference between two consecutive stable isotope samples in years. Hiatuses in individual records are shown by blank spaces. 
As described in Section 2, the primary controls on speleothem $\delta^{18} \mathrm{O}$ vary substantially across North and Central America, providing the opportunity to reconstruct many important components of the climate system in different locations and to investigate teleconnections between these components. However, this variability clearly necessitates a place-based understanding of modern climate and in-cave controls at each study site, as well as consideration of how these processes may operate on multiple timescales, from seasonal to orbital. Presently, the temporal coverage of speleothem records is uneven across the region, allowing the investigation of different aspects of the climate system at different time periods, but precluding a comprehensive view of climate from the tropics to the mid-latitudes and from the glacial period through modern for the region as a whole. This is apparent when comparing the range and variance of $\delta^{18} \mathrm{O}_{\text {spel }}$ values during the LGM versus the Holocene (Figure 4), which hints at a more negative and more variable $\delta^{18} \mathrm{O}_{\text {spel }}$ during the glacial, with higher latitude records displaying more variance than low latitude records. This observation is consistent with a synthesis of global temperature proxies that suggest more variable temperatures during the LGM compared to the Holocene at high latitudes compared to the tropics [97]. However, in our case this comparison also demonstrates the lack of overlap in individual records that cover both periods.

\subsection{Monitoring and Instrumental Data Availability}

Local climate and precipitation data as well as information from cave monitoring studies provide essential frameworks for interpreting isotopic and geochemical data from speleothems [98]. Multi-year studies of $\delta^{18} \mathrm{O}$ variability in precipitation can help to pinpoint the dominant controls on this parameter. Similar analysis of cave drip water $\delta^{18} \mathrm{O}$ on event to seasonal timescales within caves can shed light on the extent to which precipitation signals are transmitted through or modified within the epikarst.

Cave monitoring for at least one season has been made at 9 of the 22 cave sites included in SISAL_v1. Monitoring has also occurred at DeSoto Caverns in Alabama, USA [99]. Monitoring at Black Chasm Caverns, California, USA [32] is used to interpret the speleothem records from nearby Moaning and McLean's Caves [45]. Several multi-year cave monitoring studies in North America have made valuable contributions to our understanding of how cave environment influences speleothem records. In particular, analysis of calcite grown in situ and drip water from caves in Florida, Texas, and Barbados has been used to assess isotopic equilibrium during carbonate precipitation [100] and to develop an empirical relationship for water-calcite oxygen isotope fractionation that is specific to cave environments [101]. Furthermore, cave monitoring in central Texas has documented the important control of cave ventilation on speleothem and drip water $\delta^{13} \mathrm{C}$ and $\mathrm{Mg} / \mathrm{Ca}$ and $\mathrm{Sr} / \mathrm{Ca}$ that reflect $\mathrm{CO}_{2}$ degassing and prior calcite precipitation [102-104].

Only a few caves have completed tests for apparent oxygen isotopic equilibrium with cave drip waters or contain records that have been replicated. Although it may be difficult to demonstrate equilibrium with certainty, it is important to determine the extent to which speleothem oxygen isotope records may be influenced by in-cave processes that may or may not reflect climate variability. In some cases, it is clear that material has precipitated far out of oxygen isotopic equilibrium and thus records are not clear indicators of environmental change $[105,106]$. 

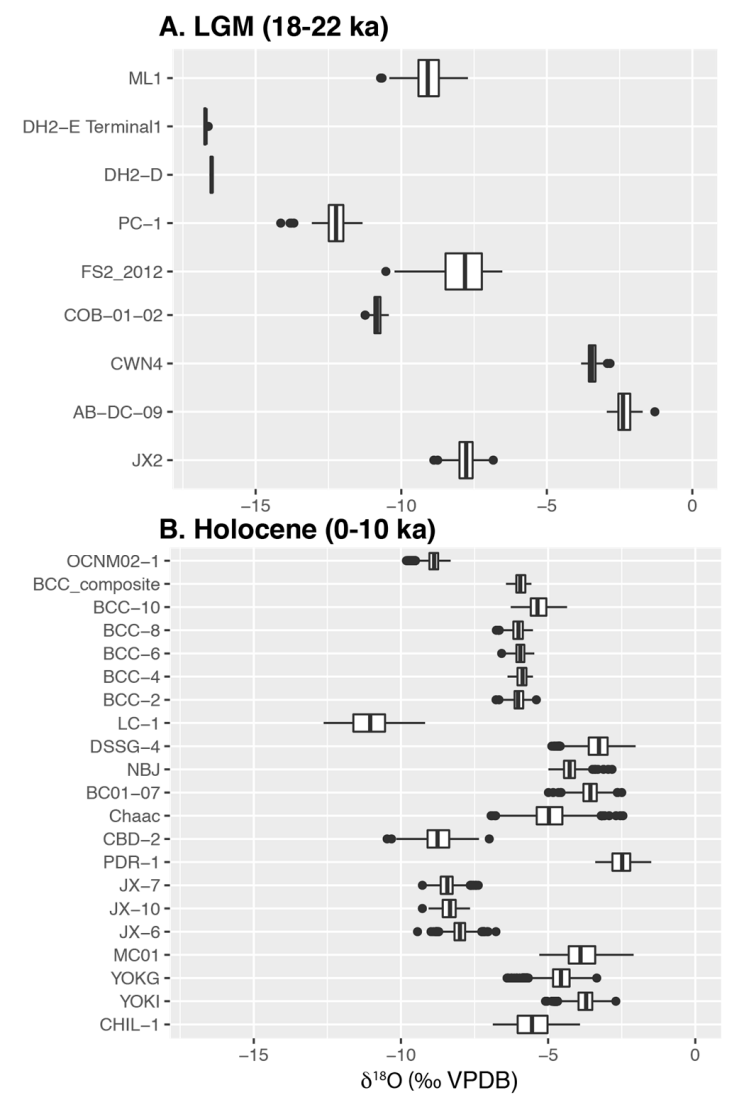

Figure 4. Box and whisker plots comparing (A) LGM (18-22 ka) and (B) Holocene (0-10 ka) values of $\delta^{18} \mathrm{O}_{\text {spel }}$. Records are arranged by latitude, with lower latitude records at the bottom of each panel. Center lines are median values and box hinges represent the first and third quantiles. Whiskers extend to the highest and lowest values with points plotted beyond the whiskers considered as outliers.

\section{Patterns in $\delta^{18} \mathrm{O}_{\text {spel }}$ in North and Central America through Time}

To document observed patterns in $\delta^{18} \mathrm{O}_{\text {spel }}$ variations during MIS 3 to 7 ( 80 to $200 \mathrm{ka}$ ), the LGM through the last deglaciation (10 to $22 \mathrm{ka}$ ), the Holocene (0 to $10 \mathrm{ka})$, and the last two millennia (0 to $2 \mathrm{ka}$ ), we use visual comparisons and statistically assess correlations between speleothem records when appropriate. We follow the approach of Rehfeld and Kurths (2014) and Oster and Kelley (2016) which uses Gaussian-kernel based smoothing to generate regularly sampled estimates that follow the pattern of change observed in the original irregularly sampled speleothem time series $[29,107]$. We use the MATLAB toolbox NESToolbox [107] to compute Pearson correlation of these Gaussian smoothed records, termed Gaussian-kernel-based cross-correlation ( $\mathrm{gXCF}$ ), to identify positive or negative correlations between speleothem records. We applied linear detrending to the raw data series prior to $\mathrm{gXCF}$ analysis by taking the residuals from a linear function $\mathrm{y}=\mathrm{a}+\mathrm{bt}$ fitted to the original data series. This was done to remove correlations between records that simply reflect long-term change in the climate system. Pairs of these detrended data-series were compared using the similarity function in NESToolbox using the gXCF option with bandwidth selection following the recommended $\mathrm{h}=0.25$ for the common sampling interval on the rescaled time-axis which is the default setting within NESToolbox. We conduct all comparisons with zero temporal lag between records. Time series data are centralized and standardized within NESToolbox prior to gXCF calculation. Significance of $\mathrm{gXCF}$ values was evaluated by comparison with independent $\mathrm{AR}(1)$ autocorrelated but mutually uncorrelated surrogate time series generated using NESToolbox. Correlation values that fall outside the 5\% and 95\% quantiles drawn from 2000 replicate surrogate testing are accepted as significant [107]. We then visualize the significant gXCF values between records of each time period (if there are any) 
on a network diagram. We construct these diagrams using the qgraph package in $R$ [108] with node placement determined geographically.

\subsection{Late Pleistocene}

\subsubsection{Pre-LGM}

Pre-LGM climate in North and Central America is mostly recorded in lower temporal resolution records. Records covering Marine Isotope Stage 7 (MIS7) through MIS5 include the Devil's Hole vein calcites, records from Lehman and Leviathan Caves in Nevada, and Buckeye Creek Cave in West Virginia (Figure 5). MIS3 is covered by records from Abaco Island in the Bahamas, the Fort Stanton (FS2-2012) and Cave of the Bells (COB02-01) records in southwestern North America, and Leviathan Cave. Temporal coverage of records across this time and region is too variable to warrant a statistical comparison.

MIS 3 is characterized by globally resolved millennial-scale Dansgaard/Oeschger (D/O) events, recorded in the Greenland ice cores as periods of warming, followed by a gradual return to cooler temperatures [109]. The southwestern North American speleothems (FS2-2012, COB-01-02) demonstrate more positive $\delta^{18} \mathrm{O}_{\text {spel }}$ values associated with interstadials, interpreted as enhanced aridity or less winter precipitation associated with D/O events [5,40]. A California speleothem record not included in SISAL_v1 also displays increased aridity during D/O stadials of MIS4 and early MIS3 [110]. Stalagmites AB-DC-01 and AB-DC-12 from Abaco Island, Bahamas demonstrate more negative $\delta^{18} \mathrm{O}_{\text {spel }}$ values associated with interstadials interpreted as either warmer or wetter periods in the Bahamas [92].

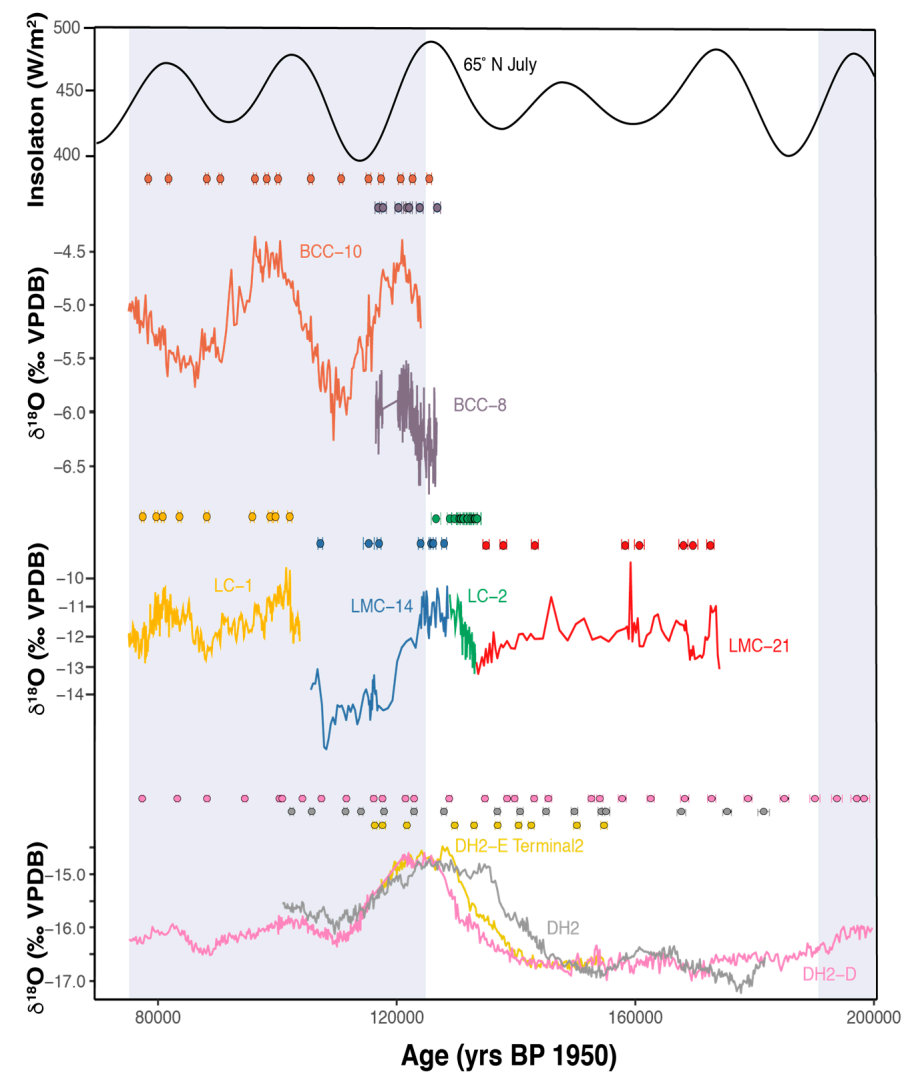

Figure 5. Speleothem records covering MIS5 to MIS7 that are included in SISAL_v1. These include vadose zone (LMC and LC records $[47,111]$ which comprise the Leviathan Chronology) and phreatic deposits from western North America (DH records [96]), as well as records from the eastern United States (BCC records [112]), and the record of July insolation at $65^{\circ} \mathrm{N}$ [113]. Ages (solid circles) and associated uncertainties are shown with each record. Interglacial periods MIS5 and MIS7 are shaded blue. 
The longest accurately-dated speleothem $\delta^{18} \mathrm{O}$ record from the western United States comes from a combination from Leviathan, Pinnacle, and Lehman Caves, Nevada, called the Leviathan Chronology. These data show that $\delta^{18} \mathrm{O}_{\text {spel }}$ variations over the past 175,000 years closely follow the pacing and amplitude of variations in Northern Hemisphere summer insolation. The Great Basin $\delta^{18} \mathrm{O}_{\text {spel }}$ records also display termination ages, marked by increased $\delta^{18} \mathrm{O}$, that are in phase with increases boreal summer insolation $[3,47,48,111]$. In the Leviathan Chronology, shifts in $\delta^{18} \mathrm{O}_{\text {spel }}$ lag the precession cycle in boreal summer insolation by on average 3240 years [47]. The mechanism which links northern hemisphere summer insolation and $\delta^{18} \mathrm{O}_{\text {spel }}$ is thought to be changes in Arctic sea ice extent. When insolation is low, sea ice extent is greater, driving changes in atmospheric circulation that enhance winter rainfall in the Great Basin [3]. These Nevada vadose zone $\delta^{18} \mathrm{O}_{\text {spel }}$ data were significant because they showed 'on-time' climate variations in the Great Basin in contrast to the Devils Hole phreatic calcite $\delta^{18} \mathrm{O}$ record, which exhibited shifts to more positive values at glacial terminations that appeared to precede terminations in other records by $~ 10,000$ years, e.g., [114]. In particular, the timing of the original record suggested that the isotopic shift in the groundwater that feeds Devils Hole preceded the rise in boreal insolation, suggesting that Termination II did not arise from orbital forcing. This timing created a conundrum for how such mid-latitude changes could lead change in high latitude insolation [96] or suggested that the Devils Hole record must contain imprints of non-climatic processes [3,47]. Recent redating of the Devils Hole core has helped to resolve this controversy [96] by suggesting that non-replicated dating of isotopic anomalies of calcite can be attributed to ${ }^{230} \mathrm{Th}$ mobilization and dynamics in the groundwater column. This effect is thought to be especially pronounced during terminations when the water table is high. Considering the effect of a depth gradient in ${ }^{230} \mathrm{Th}$ in the groundwater column, the authors suggested that cores collected at higher elevations within Devils Hole should have the most accurate chronology [96], placing the ages of the terminations closer to—-but lagging behind—-those in the vadose zone records [3].

\subsubsection{Last Glacial Maximum and Deglaciation}

The SISAL_v1 database contains 13 speleothems from North and Central America that cover the interval between 22 and $10 \mathrm{ka}$. We focus on 10 of these (Figure 6) because the two Devils Hole cores that cover this interval are of lower temporal resolution (Section 4.1.1), and we only use the most recently published (FS2 2012) of the two versions of the Fort Stanton Cave record in the database. Coverage of the LGM and deglacial period in SISAL_v1 is particularly strong in western North America, with records from seven caves covering at least 2000 years of this interval (ML1, MC3, LC-1, PC-1, FS2-2012, COB-01-02, and CWN4) (Figure 6). Three speleothems from two cave sites in the lower latitudes cover this interval, AB-DC-03 and AB-DC-09 from Abaco Island, Bahamas, and JX2 from Juxtlahuaca Cave in Mexico. Visually, these records show important similarities across this interval of significant global climate change. Particularly noticeable are changes at end of Heinrich Stadial 1 (HS1) and the onset of the Bölling warm period at 14.5 ka (Figure 6). Records FS2-2012, COB-01-02, and MC3 from western North America show shifts to more positive $\delta^{18} \mathrm{O}$ values within age errors of each other and of this transitional period noted in the NGRIP $\delta^{18} \mathrm{O}$ record of temperature [115]. Records CWN4 from Texas and the Abaco Island speleothems from the Bahamas show the opposite shift, with $\delta^{18} \mathrm{O}_{\text {spel }}$ decreasing across this interval. In western North America, records ML1, MC3, LC-1, FS2-2012, and COB-01-02 display shifts to more negative $\delta^{18} \mathrm{O}_{\text {spel }}$ heading into the Younger Dryas cold period at $\sim 12.8 \mathrm{ka}$ (Figure 6). Likewise, the CWN4 record shows a positive shift leading into this period before a growth hiatus begins at $\sim 12.5 \mathrm{ka}$.

These visually-apparent relationships can also be noted statistically (Figure 7, Table 2). The records from the Great Basin and southwest (FS2-2012, COB-01-02, and LC-1) are positively correlated to each other and negatively correlated to the CWN4 record and the tropical records from the Bahamas and Mexico. Weak positive correlations are also apparent between the records from the Bahamas and Mexico and the speleothem records from the Sierra Nevada in California. These correlations 
suggest similar or related climate mechanisms lead to concurrent shifts in precipitation, and therefore speleothem, $\delta^{18} \mathrm{O}$ across this region during the last deglaciation.

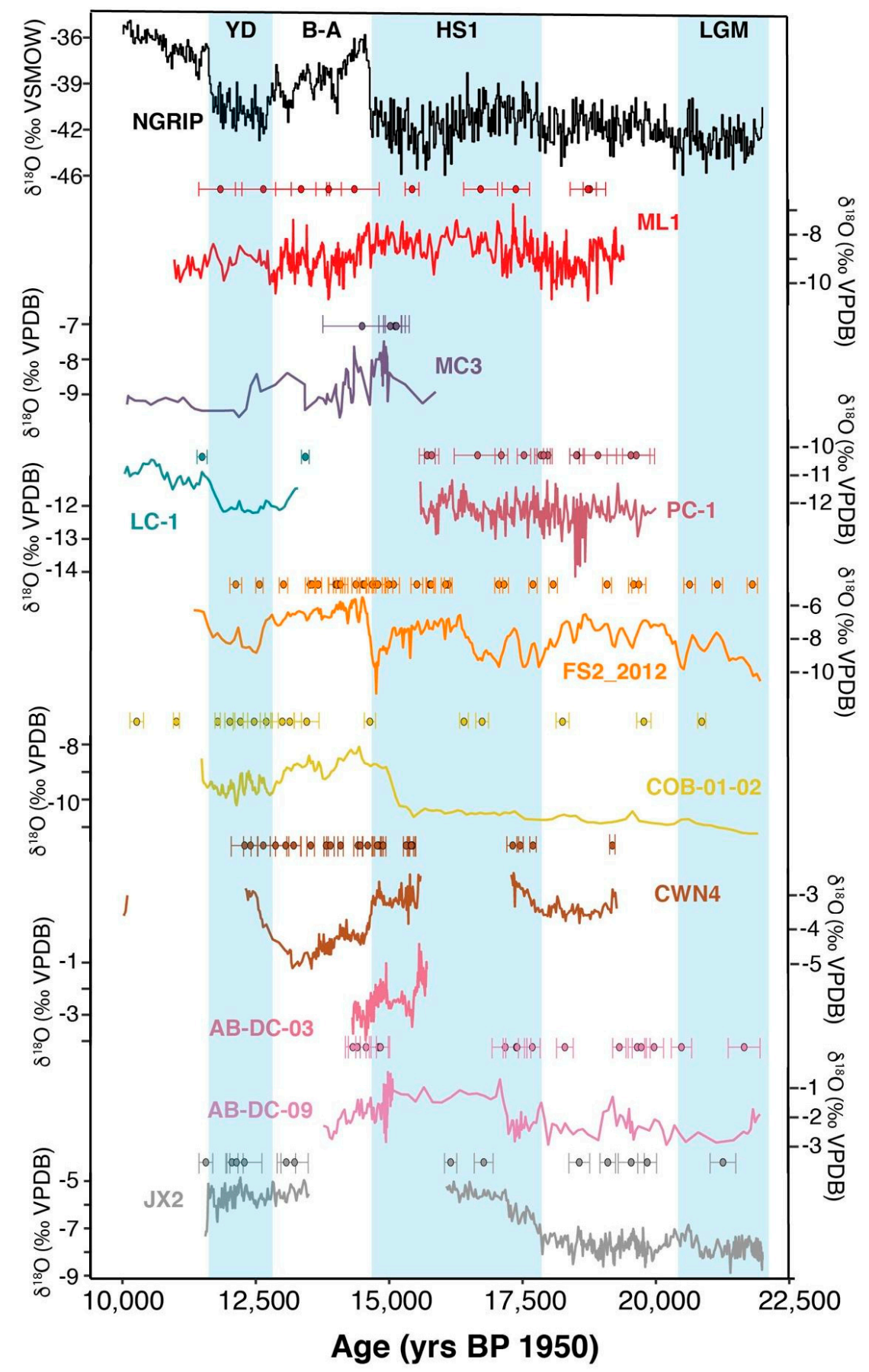

Figure 6. Speleothem records covering the LGM through the most recent deglaciation that are included in SISAL_v1 compared to the NGRIP $\delta^{18} \mathrm{O}$ record from Greenland [115]. See Table 1 for record details. Ages (solid circles) and associated uncertainties are shown with each record. Periods of Northern Hemisphere cooling are highlighted in blue. Records are arranged by latitude. 


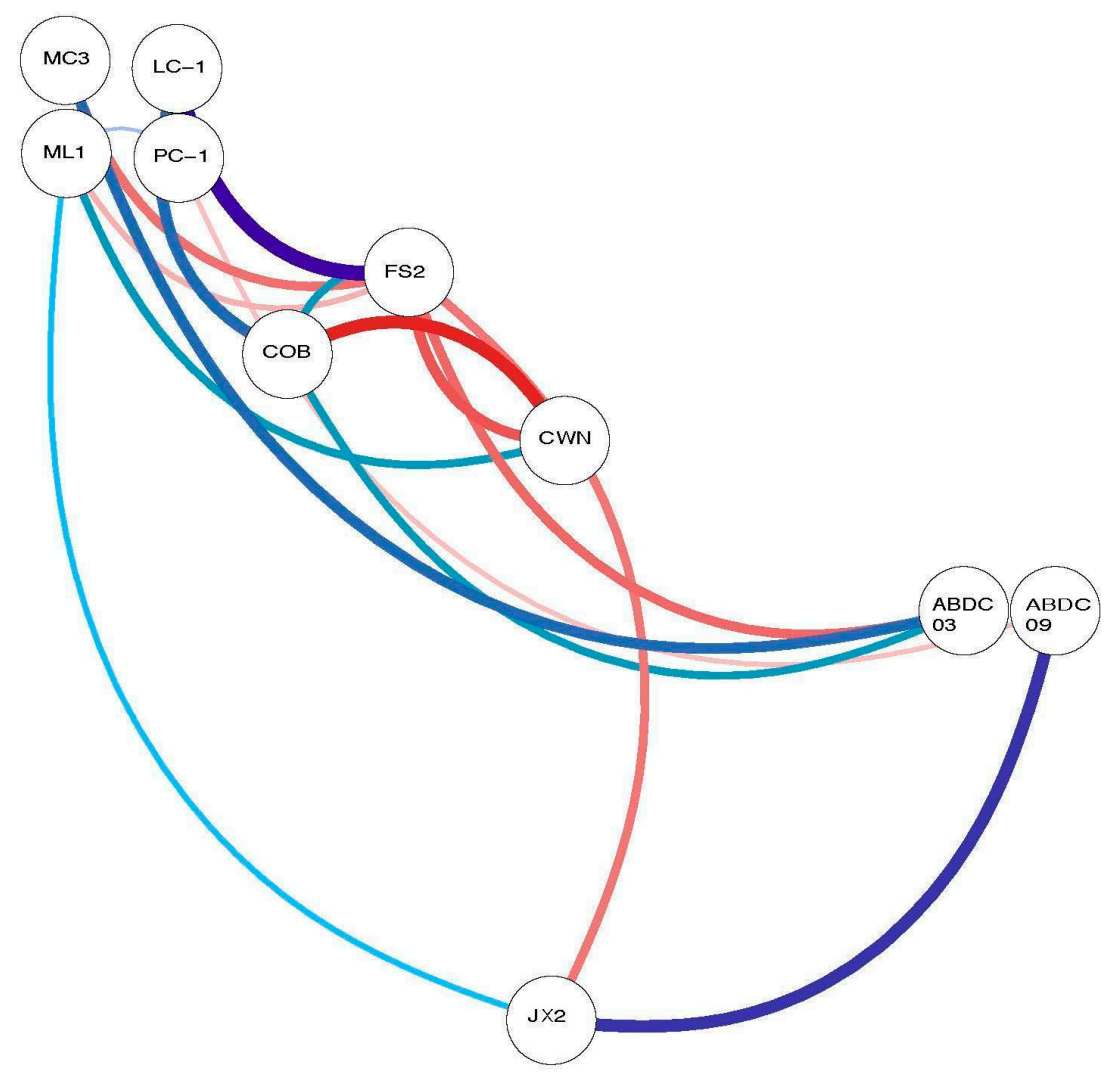

Figure 7. Network plot for deglacial speleothem records included in SISAL_v1 shown at zero temporal lag with sites arranged geographically. Correlation $(\mathrm{gXCF})$ strength increases with width of line and depth of color. Blue lines represent positive correlations and red lines represent negative ones. These relationships are computed over the amount of time that each pair of records overlaps, so each relationship covers a slightly different temporal interval within the 10-22 ka window. Only correlations that fall outside of the 5 and 95\% quantiles drawn from 2000 replicate surrogate testing plotted. Pairwise gXCF values are shown in Table 2. Records shown are from Abaco Island (ABDC), Cave of the Bells (COB), Cave without a Name (CWN), Fort Stanton Cave (FS2), Juxtlahuaca cave (JX2), Leviathan Cave (LC), Moaning Cave (MC), McLean's Cave (ML), and Pinnacle Cave (PC).

The LGM and deglacial climate of North and Central America is influenced by a number of drivers including the presence and decay of the Laurentide ice sheet, glacial meltwater discharge and changes in ocean circulation, and insolation variations. Each of these factors drive changes in atmospheric circulation that influence precipitation, and therefore speleothem $\delta^{18} \mathrm{O}$ in different ways across this region. At the LGM, squeezing and deflection of westerly winds and steering of storms along a northwest to southeast trend due to the pressure gradient caused by the high-pressure system over the Laurentide ice sheet increased moisture delivery to southwestern North America [4]. This may have coincided with an increased contribution from southwesterly AR events, with impacts shifted away from the Pacific Northwest and toward the southwest [49] (Figure 2B). The change in the westerly winds advected colder air into southwestern North America, reducing the energy flux needed to drive the North American Monsoon [50] (Figure 2B). Together, these processes enhanced the contribution of winter westerly storm precipitation to the southwest, reducing $\delta^{18} \mathrm{O}$ in speleothems FS2-2012 and COB-01-02 (Figure 6).

In southern Mexico, the more negative $\delta^{18} \mathrm{O}_{\text {spel }}$ values in stalagmite JX2 are interpreted to reflect a relatively active Mesoamerican monsoon during the LGM [116]. However, JX2 $\delta^{18} \mathrm{O}_{\text {spel }}$ values increase during Heinrich Stadial 1 (HS1), suggesting a reduction in the monsoon, possibly due to a southward shift of the ITCZ following meltwater inputs in the North Atlantic [116]. This is consistent with recent modeling experiments and climate records that advocate for a meridional shift of the 
rainbelt, rather than an expansion or contraction, in response to asymmetric extra-tropical forcing such as freshwater hosing [117-120]. The positive shift in JX2 during HS1 is concurrent with a rise in $\delta^{18} \mathrm{O}_{\text {spel }}$ at Abaco Island, Bahamas that is interpreted to reflect colder temperatures [91,92] and underlies the positive correlation between these two records (Figure 7). In western North America, the climate of HS1 is considered to be wetter than that of the LGM, as many pluvial lakes are high at this time [121,122]. Hosing experiments suggest that this increased moisture is caused by an intensified subtropical jet and a deepened Aleutian low, which may be related to the southward shifted ITCZ [123]. It is thought that the increased moisture is derived from southwesterly ARs, which may be consistent with a small increase in $\delta^{18} \mathrm{O}_{\text {spel }}$ in stalagmite ML1 from the western Sierra Nevada and can explain the positive correlation between ML1 and JX2 (Figure 7). Other western North America stalagmites display variable responses to HS1. The COB-02-01 and PC-1 stalagmites do not show substantial variations in $\delta^{18} \mathrm{O}_{\text {spel }}$ over HS1 (Figure 6). However, increased precipitation in Nevada is suggested by a decrease in $\delta^{13} \mathrm{C}$ values during HS1 in PC-1 from Pinnacle Cave, Nevada [124]. Stalagmite FS2-2012 shows first a decrease and then an increase in $\delta^{18} \mathrm{O}_{\text {spel }}$, which may reflect a two-phase HS1 suggested by lake records that are proximal to Fort Stanton Cave [125].

Toward the end of HS1, a reduction in $\delta^{18} \mathrm{O}_{\text {spel }}$ in the Texas stalagmite CWN4 is interpreted to reflect lower surface water $\delta^{18} \mathrm{O}$ in the Gulf of Mexico due to the input of glacial meltwater flowing through the Mississippi River [18]. Concurrent increases in $\delta^{18} \mathrm{O}_{\text {spel }}$ in FS2-2012 and COB-01-02 at the start of the Bölling-Alleröd may reflect a decrease in the proportion of winter precipitation or an increase in relatively higher $\delta^{18} \mathrm{O}$ Gulf moisture reaching the southwest. In Abaco Island, this transition is noted as a decrease in $\delta^{18} \mathrm{O}_{\text {spel }}$ in two stalagmites caused by warming temperatures. The Younger Dryas is marked by decreased $\delta^{18} \mathrm{O}_{\text {spel }}$ in LC-1, FS2-2012, COB-01-02, and MC3 which supports increased winter moisture and colder temperatures potentially related to an intensified storm track resulting from enhanced meltwater flux to the North Atlantic [126]. Speleothem $\delta^{18} \mathrm{O}$ increases up to a hiatus in CWN4 reflecting reduced glacial meltwater in the Gulf of Mexico, and ultimately drier conditions in central Texas, underlying the negative correlation between CWN4 and the southwestern and Great Basin speleothem records (Figure 7).

\subsection{Holocene}

\subsubsection{Early and Middle Holocene}

The early and middle Holocene is represented by scattered records across Central and North America. These include Cueva del Diablo (stalagmite CBD-2) from southern Mexico, Brown's Cave (BC01-07) from Florida, Natural Bridge Caverns in central Texas (NBJ), DeSoto Caverns in Alabama (DSSG-4), Buckeye Creek Cave in Western Virginia (several BCC stalagmites), Leviathan Cave in Nevada (LC-1), and Oregon Caves National Monument (OCNM02-01) (Figure 8). Complete coverage of the Holocene is only available in stalagmite LC-1. Temporal coverage and resolution are quite variable in the early to mid-Holocene records, and this likely contributes to the lack of significant correlations among them. 


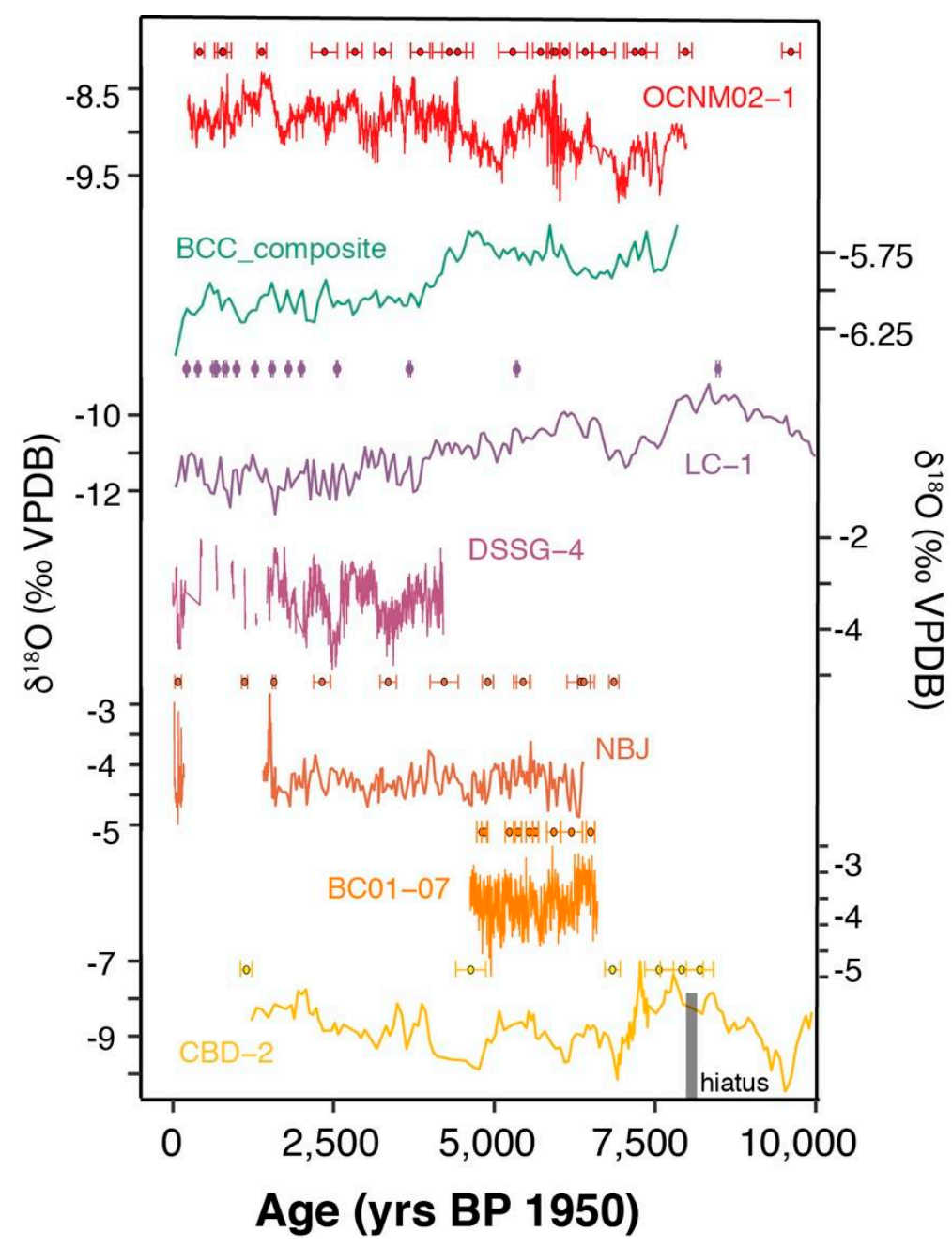

Figure 8. Speleothem records covering the Holocene in SISAL_v1 that include the early and middle Holocene. See Table 1 for record details. Ages (solid circles) and associated uncertainties are shown with each record. Records are arranged by latitude.

The small number of Holocene speleothem records from western North America may reflect widespread aridity during the early and middle Holocene, e.g., [127]. The Holocene LC-1 record shows an increase in $\delta^{18} \mathrm{O}_{\text {spel }}$ beginning in the early Holocene, a peak in $\delta^{18} \mathrm{O}$ values around $8.0 \mathrm{ka}$, and a decrease to the present. This pattern of $\delta^{18} \mathrm{O}_{\text {spel }}$ change is consistent with a lagged response to summer insolation, potentially related to the lagged response of the Arctic cryosphere to summer insolation, as variations in Arctic sea ice could influence on the intensity of Pacific winter storms [3]. The OCNM02-01 record on the other hand, has been tied to changes in northeast Pacific sea surface temperature and winter insolation [42]. The $8.2 \mathrm{ka}$ event is recorded in a high-resolution coastal California speleothem that is not included in SISAL_v1 [44] as a period of enhanced winter storminess. However, further inland LC-1 shows the highest $\delta^{18} \mathrm{O}_{\text {spel }}$ at this time and no evidence of an $8.2 \mathrm{ka}$ cold event $[3,47]$. A hiatus in stalagmite CBD-2 suggests dry conditions in southern Mexico during this event [128], but the drying encompasses a much broader temporal window than the short 8.2 ka event. In eastern North America, the BCC record from West Virginia displays a shift to lower values at $4.2 \mathrm{ka}$ (Figure 8), which is coincident with a step-change to lower $\delta^{18} \mathrm{O}_{\text {spel }}$ in the Great Basin [47]. This shift in the eastern United States was interpreted to reflect a reduction in summer, Gulf of Mexico-derived precipitation and is coincident with many other records of hydrologic change across the globe [67]. More early to middle Holocene speleothem records from North and Central America are needed to provide a detailed picture of climate change during this time. 


\subsubsection{Last 2000 Years}

There are 16 records covering the last 2000 years in SISAL_v1 in Central America and the Caribbean, of which the nine speleothems with the highest resolution are shown in Figure 9. These comprise one record from the northern Yucatan peninsula (Tzabnah Cave, Mexico), three speleothems from Belize (southern Yucatan, Yok Balum Cave and Macal Chasm Cave), two from western Mexico (Juxtlahuaca Cave), one from Puerto Rico (Perdida Cave), and one speleothem from each the lower latitudes on the isthmus of Panama (Chillibrillo Cave) and the higher latitudes on the northern American continent (Oregon Caves National Monument).

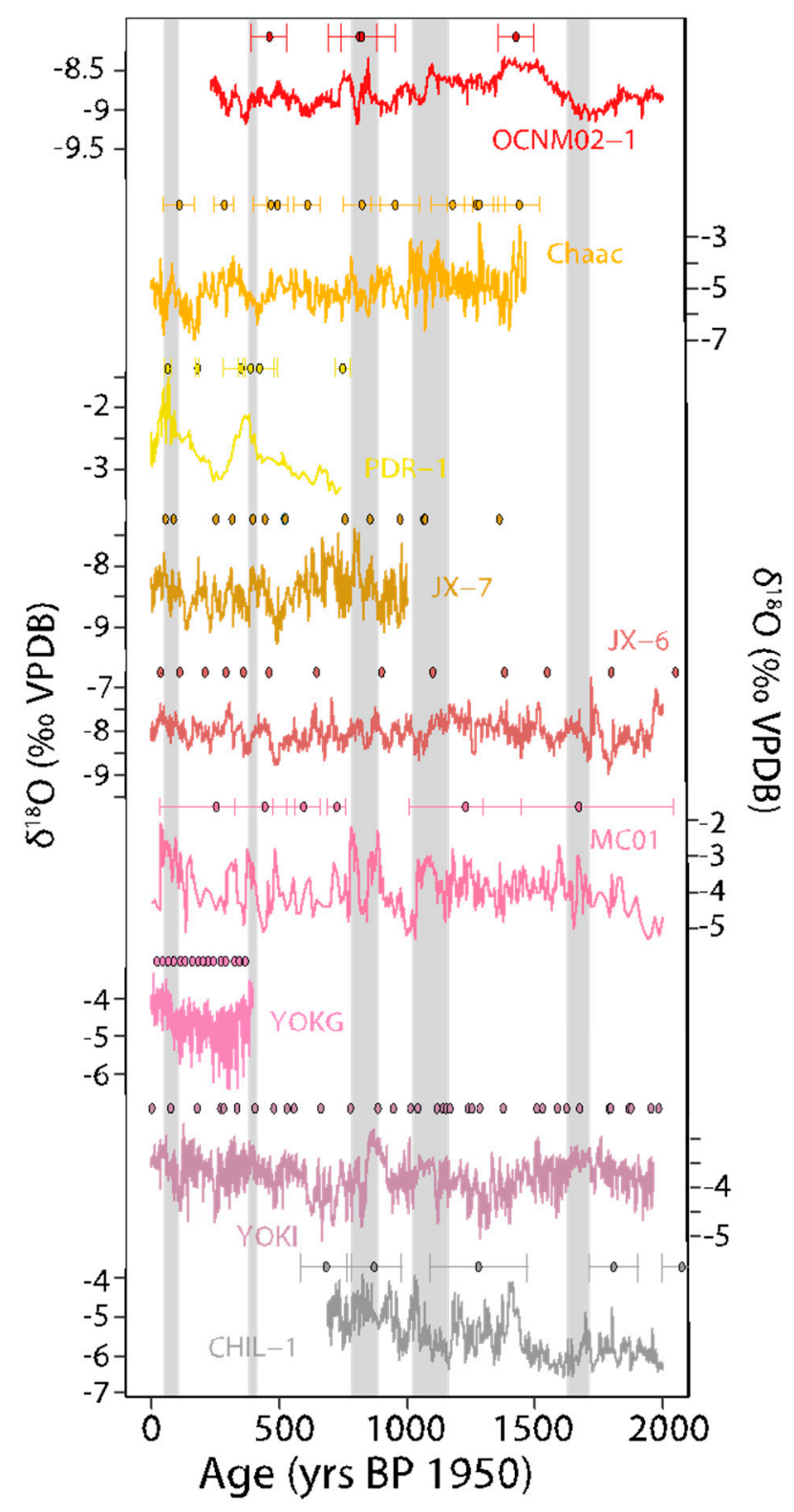

Figure 9. Speleothem records covering the last 2000 years at approximately decadal resolution or better that are included in SISAL_v1. See Table 1 for record details. Ages (solid circles) and associated uncertainties are shown with each record. Records are arranged by latitude.

Oxygen isotope values in speleothem PDR-1 from Puerto Rico during the last 800 years are characterized by a pronounced multi-decadal variability [129]. Moving from Puerto Rico towards the west, speleothem records from central America show a multi-decadal pattern superimposed upon several multicentennial-scale trends during the last 2000 years BP $[8,9]$. Interpreting $\delta^{18} \mathrm{O}_{\text {spel }}$ in the 
Central American speleothems as a proxy for precipitation amount, the $\delta^{18} \mathrm{O}_{\text {spel }}$ records from Yucatan and also western Mexico show a series of droughts during the last millennia [9,93,129-131]. These major dry events (marked with vertical bars in Figure 9) are particularly pronounced in MC01 from Belize, where major dry events (MDE) were identified between 2840-3060, 2500-2540, 2060-2140, 1600-1700, 1050-1200, 750-900, 370-420, and 40-100 cal yr BP [8]. The timing of drought in the Mexico highlands (JX6, JX-7) may have preceded that in the lowlands (YOKG, MC01, YOKI) [9]. Major dry events are evident in most Central American and Caribbean $\delta^{18} \mathrm{O}_{\text {spel }}$ records suggesting a common regional forcing. Correlation analyses (Figure 10) show a positive correlation of Central American speleothem records to both PDR-1 (Puerto Rico) and OCNM (Oregon, United States). The strongest positive connection appears between the PDR-1 and MC01 in Belize, whereas no significant correlation was derived for PDR-1 to the speleothem records located towards the west. This supports the observation of an E-W-gradient of multidecadal versus centennial scale patterns, indicating that the influence of the North Atlantic diminishes when moving across central America towards the west. This common pattern is presumably the influence of North Atlantic Sea surface temperatures, which modulate the meridional temperature gradient and consequently the strength of the trade winds and the CLLJ, transporting moisture westwards into the Caribbean basin. Locations further west are less influenced by the eastern trades and the CLLJ, but receive more moisture from Pacific sources. This, in turn, is indicative of a more dominant influence of ENSO activity in speleothems from mid and western Central America, as proposed for many of these records $[6,8,9,130]$

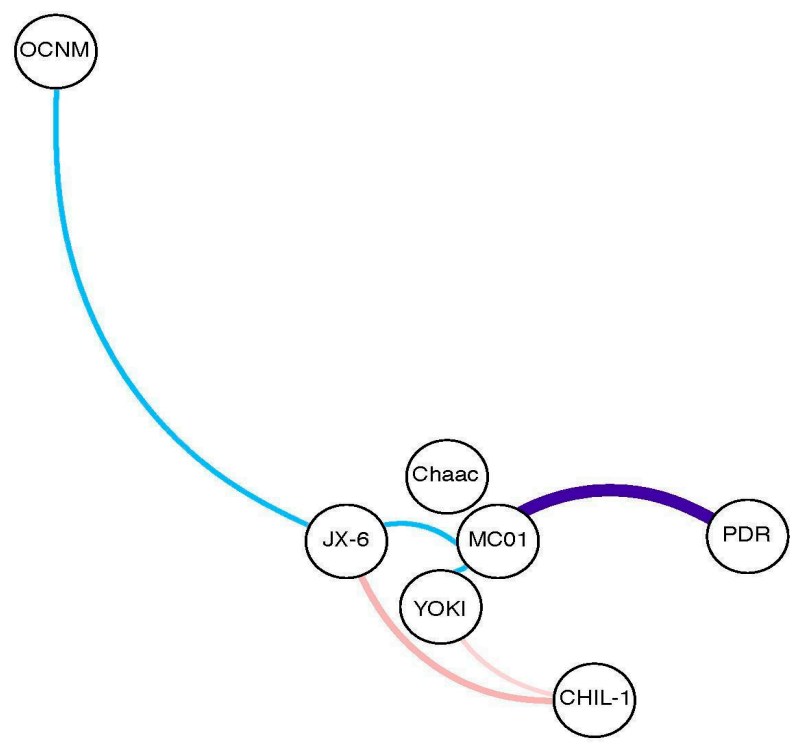

Figure 10. Network plot for high resolution records covering the last 2000 years. See Figure 7 for further details. Pairwise gXCF values are shown in Table 2. Records shown are from Chilbrillo Cave (CHIL-1), Juxtlahuaca Cave (JX-6), Machal Chasm (MC01), Oregon Caves National Monument (OCNM), Perdida Cave (PDR), Tzabnah Cave (Chaac), and Yok Balum Cave (YOKI).

A negative correlation is observed between $\delta^{18} \mathrm{O}_{\text {spel }}$ of CHIL-1, the southernmost record from the Isthmus of Panama, and both YOKI (Belize) and JX-6 (Mexico). A number of precipitation-based records suggest that the seasonal extremes of the ITCZ rainbelt respond to local summer insolation, and consequently the rainbelt seasonal range undergoes latitudinal migrations [10,132-136]. Other evidence suggests that the ITCZ rainbelt contracted/expanded around its mean position [120,137-139]. According to this argument, asymmetric extratropical forcings like ice sheets or freshwater hosing produce meridional shifts in the zonal mean rainbelt, but orbital variations produce expansion/contractions in terms of the global zonal mean [120]. However, the driving regional mechanisms still remain elusive since the dynamic response of the rainbelt variation is regionally variable, depending on surface type (land or ocean) and surrounding continental configuration [10,120]. 
For the monsoon domain of southwestern Mexico, a precisely-dated ( $<10-y e a r$ precision) and replicated $\delta^{18} \mathrm{O}_{\text {spel }}$ record from Juxtlahuaca Cave, Mexico (JX-6 and JX-7) shows a combined Atlantic and Pacific control of rainfall amount. The JX $\delta^{18} \mathrm{O}_{\text {spel }}$ record is correlated with both the North Atlantic Oscillation reconstruction and with a tree-ring based reconstruction of ENSO [130]. These data suggest that ocean-atmosphere variations in both the Atlantic and Pacific Ocean are important controls on climate dynamics in southwestern Mexico and Central America.

There is also evidence for the influence of aerosol forcing by volcanic and human activity on Mesoamerican rainfall variability from Belize [140,141]. Both studies provide evidence of long-lasting volcanic effects on precipitation changes in Mesoamerica during the past centuries. However, the authors also note, that direct climate effects cannot be attributed to volcanic aerosol forcing alone, but may have exacerbated or prolonged the drought intervals beyond the duration of the direct radiative imbalance [140-142]. In summary, this makes interpretation of precipitation-proxy records as large-scale rainbelt movement challenging, requiring regional or global data syntheses.

\section{Improvements to SISAL for North and Central America}

Speleothems from North America have provided an important background understanding of continental to regional scale paleoclimate information. In the low latitudes, the climatic information is primarily related to precipitation amount and monsoon strength. In the higher latitudes, temperature and moisture source appear to be the dominant controls on $\delta^{18} \mathrm{O}_{\text {spel }}$ values. The tropical records suggest a combined insolation and Atlantic Ocean circulation control on $\delta^{18} \mathrm{O}_{\text {spel }}$ values, with continental records showing high $\delta^{18} \mathrm{O}$ values during monsoon weakenings during HS1 and the Younger Dryas, and the Abaco Island record suggesting a strong temperature control on $\delta^{18} \mathrm{O}_{\text {spel }}$. These data suggest that climate over much of the Caribbean and Central America is driven by Atlantic Ocean forcing. For the desert regions of southwestern United States exclusive of the Great Basin, clear D/O-type variability suggests that the variations in winter to summer precipitation amount are strong controls on climate. For the Great Basin speleothem records, a clear forcing from northern hemisphere summer insolation is evident, which may be related to teleconnections between the Arctic, Pacific Ocean, and western United States circulation.

Central and North America are characterized by vast variations in climate, atmospheric processes, geography, geology and climate history. Given this diversity and the lack of overlap among current records, greater spatial and temporal coverage by speleothem records is necessary to gain a more complete picture of paleoclimate change across this region over the past 200,000 years. Identified published speleothem records that are not included in SISAL_v1 do improve this outlook (Figure 1; Table 1), and the SISAL working group will aim towards including these in future versions of the SISAL database [1]. Yet even with these contributions, greater temporal coverage is needed across North and Central America for all time periods and new records should be developed. In particular, there are currently few records available from MIS3 and older. Additional high-resolution records are necessary to assess spatial trends in rapid climate change events such as D/O, Heinrich Stadials and the deglaciation. More records are necessary from the last 2,000 years to more fully assess anthropogenic impacts on the environment. In addition to the development of speleothem records, comprehensive monitoring programs are needed to assess modern influences on speleothem geochemistry to aid with constraining the environmental influences on speleothem geochemistry in the past. Speleothem researchers should also attempt to provide replicated and near-equilibrium records from within the same cave to ensure that the speleothem $\delta^{18} \mathrm{O}$ is accurately encoding climatic change [143,144]. Lastly, future work should include identification of caves with suitable uranium-series geochemical characteristics to produce the precise chronologies necessary to advance our understanding of the timing of paleoclimatic change in this region. 
Table 1. Identified North and Central American speleothem records.

\begin{tabular}{|c|c|c|c|c|c|c|c|c|c|c|c|}
\hline Site Name & Site ID & Country & Entity Name & Entity ID & Lat $\left({ }^{\circ} \mathrm{N}\right)$ & Long $\left({ }^{\circ} \mathrm{E}\right)$ & Elev. (m asl) & Min Year BP & Max Year BP & SISAL_v1 & Ref. \\
\hline Lehman Caves & 14 & United States & LMC-14 & 67 & 39.01 & -114.2 & 2080 & 105,617 & 128,604 & $\mathrm{y}$ & [47] \\
\hline Lehman Caves & 14 & United States & LMC-21 & 68 & 39.01 & -114.2 & 2080 & 133,340 & 174,096 & $\mathrm{y}$ & [47] \\
\hline Lehman Caves & 14 & United States & LC-2 & 69 & 39.01 & -114.2 & 2080 & 128,888 & 133,168 & $\mathrm{y}$ & [111] \\
\hline Cueva del Diablo & 34 & Mexico & CBD-2 & 109 & 18.19 & -99.9 & 1030 & 1220 & 10,812 & $\mathrm{y}$ & [128] \\
\hline DeSoto Caverns & 37 & United States & DSSG-4 & 112 & 33.37 & -86.4 & 150 & -58 & 4204 & $\mathrm{y}$ & [145] \\
\hline Leviathan Cave & 48 & United States & LC-1 & 124 & 37.89 & -115.6 & 2400 & -60 & 103,740 & $\mathrm{y}$ & [47] \\
\hline McLean's Cave & 49 & United States & ML1 & 125 & 38.07 & -120.4 & 300 & 10,971 & 19,391 & $\mathrm{y}$ & [45] \\
\hline Moaning Cave & 50 & United States & MC3 & 126 & 38.07 & -120.5 & 520 & 8702 & 15,870 & $\mathrm{y}$ & [45] \\
\hline Moaning Cave & 50 & United States & MC3 & 126 & 38.07 & -120.5 & 520 & 8702 & 15,870 & $\mathrm{y}$ & [43] \\
\hline Natural Bridge Caverns & 51 & United States & NBJ & 127 & 29.69 & -98.3 & 306 & 18 & 6381 & $\mathrm{y}$ & [26] \\
\hline Tzabnah Cave & 63 & Mexico & Chaac & 147 & 20.73 & -89.7 & 20 & -54 & 1463 & $\mathrm{y}$ & [93] \\
\hline Abaco Island Cave & 70 & Bahamas & AB-DC-01 & 155 & 26.23 & -77.2 & -45 & 23,699 & 28,895 & $\mathrm{y}$ & [92] \\
\hline Abaco Island Cave & 70 & Bahamas & AB-DC-03 & 156 & 26.23 & -77.2 & -45 & 14,308 & 15,704 & $\mathrm{y}$ & [92] \\
\hline Abaco Island Cave & 70 & Bahamas & AB-DC-12 & 157 & 26.23 & -77.2 & -45 & 36,122 & 63,848 & $\mathrm{y}$ & [92] \\
\hline Abaco Island Cave & 70 & Bahamas & AB-DC-09 & 158 & 26.23 & -77.2 & -45 & 13,766 & 32,076 & $\mathrm{y}$ & [91] \\
\hline Abaco Island Cave & 70 & Bahamas & AB-DC-09 & 158 & 26.23 & -77.2 & -45 & 13,766 & 32,076 & $\mathrm{y}$ & [92] \\
\hline Cave Without a Name & 75 & United States & CWN4 & 164 & 29.89 & -98.6 & 377 & 9546 & 28,490 & $\mathrm{y}$ & [18] \\
\hline Chilibrillo Cave & 78 & Panama & CHIL-1 & 167 & 9.17 & -79.6 & -79.6164 & 690 & 2180 & $\mathrm{y}$ & [6] \\
\hline Macal Chasm & 85 & Belize & MC01 & 178 & 16.88 & -89.1 & 530 & -43 & 5245 & $\mathrm{y}$ & [8] \\
\hline Macal Chasm & 85 & Belize & MC01 & 178 & 16.88 & -89.1 & 530 & -43 & 5245 & $\mathrm{y}$ & [131] \\
\hline Brown's Cave & 95 & United States & BC01-07 & 191 & 27.89 & -82.5 & 25 & 4627 & 6604 & $\mathrm{y}$ & [146] \\
\hline Yok Balum Cave & 107 & Belize & YOKI & 209 & 16.21 & -89.1 & 336 & -56 & 1965 & $\mathrm{y}$ & [7] \\
\hline Yok Balum Cave & 107 & Belize & YOKG & 210 & 16.21 & -89.1 & 336 & -34 & 399 & $\mathrm{y}$ & [140] \\
\hline Pinnacle Cave & 124 & United States & PC-1 & 259 & 35.97 & -115.5 & 1792 & 15,585 & 20,000 & $\mathrm{y}$ & [124] \\
\hline Buckeye Creek & 128 & United States & BCC-2 & 271 & 37.98 & -79.6 & 600 & 37 & 6945 & $\mathrm{y}$ & [67] \\
\hline Buckeye Creek & 128 & United States & BCC-4 & 272 & 37.98 & -79.6 & 600 & 78 & 7184 & $\mathrm{y}$ & [67] \\
\hline Buckeye Creek & 128 & United States & BCC-6 & 273 & 37.98 & -79.6 & 600 & -24 & 7848 & $\mathrm{y}$ & {$[67]$} \\
\hline Buckeye Creek & 128 & United States & BCC-8 & 274 & 37.98 & -79.6 & 600 & 116,501 & 126,712 & $\mathrm{y}$ & [112] \\
\hline Buckeye Creek & 128 & United States & BCC-10 & 275 & 37.98 & -79.6 & 600 & 41,604 & 124,036 & $\mathrm{y}$ & [112] \\
\hline Buckeye Creek & 128 & United States & BCC_composite & 276 & 37.98 & -79.6 & 600 & 37 & 7847 & $\mathrm{y}$ & [67] \\
\hline Cave of the Bells & 134 & United States & COB-01-02 & 284 & 31.75 & -110.8 & & 11,484 & 53,335 & $\mathrm{y}$ & [40] \\
\hline Juxtlahuaca Cave & 136 & Mexico & JX-6 & 286 & 17.4 & -99.2 & 934 & -60 & 2397 & $\mathrm{y}$ & [9] \\
\hline Juxtlahuaca Cave & 136 & Mexico & $J X-2$ & 287 & 17.4 & -99.2 & 934 & 11,553 & 22,061 & $\mathrm{y}$ & [116] \\
\hline Juxtlahuaca Cave & 136 & Mexico & JX-10 & 288 & 17.4 & -99.2 & 934 & 6908 & 7244 & $\mathrm{y}$ & [116] \\
\hline Juxtlahuaca Cave & 136 & Mexico & JX-7 & 289 & 17.4 & -99.2 & 934 & -7 & 1000 & $\mathrm{y}$ & [130] \\
\hline
\end{tabular}


Table 1. Cont.

\begin{tabular}{|c|c|c|c|c|c|c|c|c|c|c|c|}
\hline Site Name & Site ID & Country & Entity Name & Entity ID & Lat $\left({ }^{\circ} \mathrm{N}\right)$ & Long $\left({ }^{\circ} \mathrm{E}\right)$ & Elev. (m asl) & Min Year BP & Max Year BP & SISAL_v1 & Ref. \\
\hline Oregon caves national monument & 139 & United States & OCNM02-1 & 294 & 42.1 & -123.4 & 1300 & 234 & 7992 & $\mathrm{y}$ & [42] \\
\hline Fort Stanton Cave & 147 & United States & FS2_2012 & 321 & 33.51 & -105.4 & 1864 & 11,336 & 25,840 & $\mathrm{y}$ & [147] \\
\hline Fort Stanton Cave & 147 & United States & FS2_2010 & 322 & 33.51 & -105.4 & 1864 & 11,310 & 55,846 & $\mathrm{y}$ & [5] \\
\hline Devils Hole & 171 & United States & DH2 & 373 & 36.43 & -116.3 & 719 & 100,902 & 181,716 & $\mathrm{y}$ & [96] \\
\hline Devils Hole & 171 & United States & DH2-D & 374 & 36.43 & -116.3 & 719 & 4896 & 204,226 & $\mathrm{y}$ & [96] \\
\hline Devils Hole & 171 & United States & DH2-E Terminal1 & 375 & 36.43 & -116.3 & 719 & 5534 & 50,131 & $\mathrm{y}$ & [96] \\
\hline Devils Hole & 171 & United States & DH2-E Terminal2 & 376 & 36.43 & -116.3 & 719 & 117,435 & 154,922 & $\mathrm{y}$ & [96] \\
\hline Perdida Cave & 173 & Puerto Rico & PDR-1 & 378 & 18 & -67.0 & 1450 & -54 & 742 & $\mathrm{y}$ & [129] \\
\hline Cold water Cave & & United States & CWC-1s & & 43.47 & -92.0 & 356 & 1147 & 7774 & $\mathrm{n}$ & [148] \\
\hline Cold water Cave & & United States & CWC-2ss & & 43.47 & -92.0 & 356 & 1740 & 7270 & $\mathrm{n}$ & [148] \\
\hline Cold water Cave & & United States & CWC-3L & & 43.47 & -92.0 & 356 & 2080 & 9040 & $\mathrm{n}$ & [148] \\
\hline Devils Icebox Cave & & United States & DIB-1 & & 38.9 & -92.3 & 250 & 610 & 3500 & $\mathrm{n}$ & [149] \\
\hline Devils Icebox Cave & & United States & DIB-2 & & 38.9 & -92.3 & 250 & 2010 & 3610 & $\mathrm{n}$ & [149] \\
\hline Minnetonka Cave & & United States & MC08-1 & & 42.0875 & -111.5 & 2347 & & & $\mathrm{n}$ & [150] \\
\hline Chen Ha Cave & & Belize & CH04-02 & & 17 & -89.0 & 550 & 4631 & 7159 & $\mathrm{n}$ & [151] \\
\hline Goshute Cave & & United States & GC_2 & & 40.03 & -114.8 & 2000 & 90,169 & 101,899 & $\mathrm{n}$ & [152] \\
\hline Goshute Cave & & United States & GC_3 & & 40.03 & -114.8 & 2000 & 83,704 & 86,223 & $\mathrm{n}$ & [152] \\
\hline White Moon Cave & & United States & WMC1 & & 37 & -122.2 & 170 & 6937 & 8604 & $\mathrm{n}$ & [44] \\
\hline Arch Cave & & Canada & DM05-01 & & 50.55 & -127.1 & 660 & 9 & 12,092 & $\mathrm{n}$ & [153] \\
\hline Harrisons Cave & & Barbados & HC- 1 & & 13 & -59.0 & 300 & & & $\mathrm{n}$ & [154] \\
\hline Xibalba Cave & & Belize & GU-Xi-1 & & 16.5 & -89.0 & 350 & -57 & 251 & $\mathrm{n}$ & [141] \\
\hline Dos Anas Cave & & Cuba & CG & & 22.38 & -84.0 & 120 & -50 & 1203 & $\mathrm{n}$ & [155] \\
\hline Dos Anas Cave & & Cuba & $\mathrm{CP}$ & & 22.38 & -84.0 & 120 & 61 & 12,333 & $\mathrm{n}$ & [156] \\
\hline Santo Tomas Cave & & Cuba & $\mathrm{CM}$ & & 22.55 & -83.8 & 170 & 6850 & 9914 & $\mathrm{n}$ & [156] \\
\hline Chan Hol Cave & & Mexico & Ch-7 & & 20.16 & -87.6 & -8.5 & & & $\mathrm{n}$ & [157] \\
\hline McLean's Cave & & United States & ML2 & & 38.07 & -120.4 & 300 & 55,158 & 66,902 & $\mathrm{n}$ & [110] \\
\hline Bat Cave & & United States & BC-11 & & 32.1 & -104.3 & & & & $\mathrm{n}$ & [158] \\
\hline Crystal Cave & & United States & CRC-3 & & 36.57 & -118.8 & & & & $\mathrm{n}$ & [159] \\
\hline Ozark Caverns & & United States & OC-2 & & 38.02 & -92.0 & & & & $\mathrm{n}$ & [160] \\
\hline Bridal Cave & & United States & BC-3 & & 38.01 & -92.5 & & & & $\mathrm{n}$ & [160] \\
\hline Bridal Cave & & United States & BC-2 (2) & & 38.01 & -92.5 & & & & $\mathrm{n}$ & [160] \\
\hline Cosmic Caverns & & United States & CS-2A & & 36.26 & -93.3 & & & & $\mathrm{n}$ & [160] \\
\hline Beckham Creek Cave & & United States & BCC- 10 & & 35.57 & -93.2 & & & & $\mathrm{n}$ & {$[160]$} \\
\hline
\end{tabular}


Table 1. Cont

\begin{tabular}{|c|c|c|c|c|c|c|c|c|c|c|c|}
\hline Site Name & Site ID & Country & Entity Name & Entity ID & Lat $\left({ }^{\circ} \mathrm{N}\right)$ & Long $\left({ }^{\circ} \mathrm{E}\right)$ & Elev. (m asl) & Min Year BP & Max Year BP & SISAL_v1 & Ref. \\
\hline Mystery Cave & & United States & MC-28 & & 43.62 & -92.3 & & & & $\mathrm{n}$ & [161] \\
\hline Onondaga Caverns & & United States & $\mathrm{ON}-3$ & & 38.03 & -91.1 & & & & $\mathrm{n}$ & [160] \\
\hline Onondaga Caverns & & United States & ON-3-B & & 38.03 & -91.1 & & & & $\mathrm{n}$ & [162] \\
\hline Actun Tunichil Muknal Cave & & Belize & ATM-7 & & 17.1 & -88.9 & & & & $\mathrm{n}$ & [94] \\
\hline Crevice Cave & & United States & CCC-2 & & 37.45 & -89.5 & & & & $\mathrm{n}$ & [61] \\
\hline Crevice Cave & & United States & CCDBL-L & & 37.45 & -89.5 & & & & $\mathrm{n}$ & [61] \\
\hline Crevice Cave & & United States & CCDBL-S & & 37.45 & -89.5 & & & & $\mathrm{n}$ & [61] \\
\hline Crevice Cave & & United States & CCE-1 & & 37.45 & -89.5 & & & & $\mathrm{n}$ & [61] \\
\hline Terciopelo Cave & & Costa Rica & CT-6 & & 10.1667 & -85.3 & & & & $\mathrm{n}$ & [95] \\
\hline Terciopelo Cave & & Costa Rica & CT-7 & & 10.1667 & -85.3 & & & & $\mathrm{n}$ & [95] \\
\hline Venado Cave & & Costa Rica & V1 & & 10.1667 & -85.3 & & & & $\mathrm{n}$ & [163] \\
\hline Palco Cave & & Puerto Rico & PR-PA-1b & & 18.35 & -66.5 & & & & $\mathrm{n}$ & [164] \\
\hline Pink Panther Cave & & United States & PP-1 & & 32.08 & -105.2 & & & & $\mathrm{n}$ & [165] \\
\hline
\end{tabular}


Table 2. Timing of overlap and gXCF values for significant pairwise correlations between speleothem records for the LGM-deglacial and last 2000-year time periods.

\begin{tabular}{ccccc}
\hline Rec1 & Rec2 & Test_Start (yr BP) & Test_End (yr_BP) & gXCF \\
\hline AB-DC-09 & JX2 & 13,766 & 22,061 & 0.78 \\
COB-01-02 & FS2_2012 & 11,400 & 23,696 & 0.58 \\
JX2 & FS2_2012 & 11,552 & 22,000 & -0.52 \\
AB-DC-09 & PC-1 & 16,000 & 20,000 & -0.24 \\
FS2_2012 & MC3 & 12,000 & 16,000 & -0.54 \\
ABDC03 & MC3 & 14,300 & 15,700 & 0.66 \\
ABDC03 & COB-01-02 & 14,300 & 15,700 & 0.45 \\
ABDC03 & FS2_2012 & 14,300 & 15,700 & -0.57 \\
FS2_2012 & ML1 & 12,000 & 19,000 & -0.30 \\
PC-1 & ML1 & 16,000 & 20,000 & 0.13 \\
ML1 & JX2 & 12,000 & 19,000 & 0.32 \\
CWN4 & COB-01-02 & 11,484 & 19,264 & -0.81 \\
CWN4 & FS2_2012 & 11,336 & 19,264 & -0.64 \\
CWN4 & ML1 & 12,000 & 19,000 & 0.46 \\
LC-1 & COB-01-02 & 11,484 & 13,290 & 0.70 \\
LC-1 & FS2_2012 & 11,336 & 13,290 & 0.78 \\
MC01 & YOKI & 600 & 2000 & 0.18 \\
CHIL-1 & YOKI & 600 & 2000 & -0.10 \\
PDR-1 & MC01 & 0 & 1400 & 0.59 \\
MC01 & JX-6 & 0 & 2000 & 0.15 \\
CHIL-1 & JX-6 & 600 & 2000 & -0.17 \\
JX-6 & OCNM02-1 & 0 & 2000 & 0.14 \\
\hline
\end{tabular}

Author Contributions: All authors contributed to the collection of data and liaison with original authors of studies reviewed here. J.L.O. and S.F.W. organized and wrote the manuscript with input from all authors. All authors analyzed data, reviewed the literature, and drafted and edited figures. All authors discussed manuscript ideas, edited earlier versions, and approved this version of the manuscript.

Funding: J.L.O. acknowledges funding from the National Science Foundation (NSF grant AGS-1554998). S.F.W. acknowledges travel funding from the German Academic Exchange Service (DAAD).

Acknowledgments: We thank everyone involved in SISAL for the extraordinary work of record gathering and database construction. SISAL is a working group of the Past Global Changes (PAGES) program, and we thank PAGES for their support. We thank Sandy Harrison and Laia Comas Bru for helpful editorial comments and figure construction. This contribution benefited from helpful comments by two anonymous reviewers. We thank the World Karst Aquifer Mapping project (WOKAM) team for providing us with the karst region map presented in Figure 1.

Conflicts of Interest: The authors declare no conflict of interest.

\section{References}

1. Comas-Bru, L.; Harrison, S. SISAL: Bringing added value to speleothem research. Quaternary 2019, in press.

2. Atsawawaranunt, K.; Comas-Bru, L. The SISAL database: A global resource to document oxygen and carbon isotope records from speleothems. Earth Syst. Sci. 2018, 10, 1687-1713. [CrossRef]

3. Lachniet, M.; Asmerom, Y.; Polyak, V.; Denniston, R. Arctic cryosphere and Milankovitch forcing of Great Basin paleoclimate. Sci. Rep. 2017, 7, 12955. [CrossRef] [PubMed]

4. Oster, J.L.; Ibarra, D.E.; Winnick, M.J.; Maher, K. Steering of westerly storms over western North America at the Last Glacial Maximum. Nat. Geosci. 2015, 8, 201-205. [CrossRef]

5. Asmerom, Y.; Polyak, V.J.; Burns, S.J. Variable winter moisture in the southwestern United States linked to rapid glacial climate shifts. Nat. Geosci. 2010, 3, 114-117. [CrossRef]

6. Lachniet, M.S.; Burns, S.J.; Piperno, D.R. A 1500-year El Niño/Southern Oscillation and rainfall history for the Isthmus of Panama from speleothem calcite. JGR Atmos. 2004, 109, D20117. [CrossRef]

7. Kennett, D.J.; Breitenbach, S.F.M.; Aquino, V.V.; Asmerom, Y.; Awe, J.; Baldini, J.U.L.; Bartlein, P.; Culleton, B.J.; Ebert, C.; Jazwa, C.; et al. Development and disintegration of Maya political systems in response to climate change. Science 2012, 338, 788-791. [CrossRef] 
8. Akers, P.D.; Brook, G.A.; Railsback, L.B.; Liang, F.; Iannone, G.; Webster, J.W.; Reeder, P.P.; Cheng, H.; Edwards, R.L. An extended and higher-resolution record of climate and land use from stalagmite MC01 from Macal Chasm, Belize, revealing connections between major dry events, overall climate variability, and Maya sociopolitical changes. Palaeogeogr. Palaeoclimatol. Palaeoecol. 2016, 459, 268-288. [CrossRef]

9. Lachniet, M.S.; Bernal, J.P.; Asmerom, Y.; Polyak, V.; Piperno, D. A 2400 yr Mesoamerican rainfall reconstruction links climate and cultural change. Geology 2012, 40, 259-262. [CrossRef]

10. Lechleitner, F.A.; Breitenbach, S.F.M.; Rehfeld, K.; Ridley, H.E.; Asmerom, Y.; Prufer, K.M.; Marwan, N.; Goswami, B.; Kennett, D.J.; Aquino, V.V.; et al. Tropical rainfall over the last two millennia: Evidence for a low-latitude hydrologic seesaw. Sci. Rep. 2017, 7, 45809. [CrossRef]

11. Chen, Z.; Auler, A.S.; Bakalowicz, M.; Drew, D.; Griger, F.; Hartmann, J.; Jiang, G.; Moosdorf, N.; Richts, A.; Stevanovic, Z.; et al. The World Karst Aquifer Mapping project: Concept, mapping procedure and map of Europe. Hydrogeol. J. 2017, 25, 771-785. [CrossRef]

12. Palecki, M.A.; Angel, J.R.; Hollinger, S.E. Storm Precipitation in the United States. Part I: Meteorological Characteristics. J. Appl. Meteorol. 2005, 44, 933-946. [CrossRef]

13. Redmond, K.T.; Koch, R.W. Surface climate and streamflow variability in the western United States and their relationship to large-scale circulation indices. Water Resour. Res. 1991, 27, 2381-2399. [CrossRef]

14. Seager, R.; Hoerling, M. Atmosphere and Ocean Origins of North American Droughts. J. Clim. 2014, 27, 4581-4606. [CrossRef]

15. Cook, E.R.; Seager, R.; Cane, M.A.; Stahle, D.W. North American drought: Reconstructions, causes, and consequences. Earth-Sci. Rev. 2007, 81, 93-134. [CrossRef]

16. Cayan, D.R.; Redmond, K.T.; Riddle, L.G. ENSO and Hydrologic Extremes in the Western United States* J. Clim. 1999, 12, 2881-2893. [CrossRef]

17. Friedman, I. Stable isotope composition of waters in the Great Basin, United States 1. Air-mass trajectories. J. Geophys. Res. 2002, 107. [CrossRef]

18. Feng, W.; Casteel, R.C.; Banner, J.L.; Heinze-Fry, A. Oxygen isotope variations in rainfall, drip-water and speleothem calcite from a well-ventilated cave in Texas, USA: Assessing a new speleothem temperature proxy. Geochim. Cosmochim. Acta 2014, 127, 233-250. [CrossRef]

19. Ralph, F.M.; Dettinger, M.D. Storms, floods, and the science of atmospheric rivers. EOS Trans. Am. Geophys. Union 2011, 92, 265-266. [CrossRef]

20. Dettinger, M. Climate Change, Atmospheric Rivers, and Floods in California-A Multimodel Analysis of Storm Frequency and Magnitude Changes1. JAWRA J. Am. Water Resour. Assoc. 2011, 47, 514-523. [CrossRef]

21. Zhu, Y.; Newell, R.E. A Proposed Algorithm for Moisture Fluxes from Atmospheric Rivers. Mon. Weather Rev. 1998, 126, 725-735. [CrossRef]

22. McCabe-Glynn, S.; Johnson, K.R.; Strong, C.; Zou, Y.; Yu, J.-Y.; Sellars, S.; Welker, J.M. Isotopic signature of extreme precipitation events in the western U.S. and associated phases of Arctic and tropical climate modes. J. Geophys. Res. D Atmos. 2016, 121, 8913-8924. [CrossRef]

23. Kim, J.-S.; Kug, J.-S.; Jeong, S.-J. Intensification of terrestrial carbon cycle related to El Niño-Southern Oscillation under greenhouse warming. Nat. Commun. 2017, 8, 1674. [CrossRef] [PubMed]

24. Adams, D.K.; Comrie, A.C. The North American Monsoon. Bull. Am. Meteorol. Soc. 1997, 78, $2197-2213$. [CrossRef]

25. Metcalfe, S.E.; Barron, J.A.; Davies, S.J. The Holocene history of the North American Monsoon: "Known knowns" and "known unknowns" in understanding its spatial and temporal complexity. Quat. Sci. Rev. 2015, 120, 1-27. [CrossRef]

26. Wong, C.I.; Banner, J.L.; Musgrove, M. Holocene climate variability in Texas, USA: An integration of existing paleoclimate data and modeling with a new, high-resolution speleothem record. Quat. Sci. Rev. 2015, 127, 155-173. [CrossRef]

27. Wise, E.K. Spatiotemporal variability of the precipitation dipole transition zone in the western United States. Geophys. Res. Lett. 2010, 37. [CrossRef]

28. Hu, Q.; Feng, S.; Oglesby, R.J. Variations in North American Summer Precipitation Driven by the Atlantic Multidecadal Oscillation. J. Clim. 2011, 24, 5555-5570. [CrossRef]

29. Oster, J.L.; Kelley, N.P. Tracking regional and global teleconnections recorded by western North American speleothem records. Quat. Sci. Rev. 2016, 149, 18-33. [CrossRef] 
30. Vachon, R.W.; Welker, J.M.; White, J.W.C.; Vaughn, B.H. Monthly precipitation isoscapes $\left(\delta^{18} \mathrm{O}\right)$ of the United States: Connections with surface temperatures, moisture source conditions, and air mass trajectories. J. Geophys. Res. 2010, 115. [CrossRef]

31. Ersek, V.; Mix, A.C.; Clark, P.U. Variations of $\delta^{18} \mathrm{O}$ in rainwater from southwestern Oregon. J. Geophys. Res. 2010, 115, D09109. [CrossRef]

32. Oster, J.L.; Montañez, I.P.; Kelley, N.P. Response of a modern cave system to large seasonal precipitation variability. Geochim. Cosmochim. Acta 2012, 91, 92-108. [CrossRef]

33. Berkelhammer, M.; Stott, L.; Yoshimura, K.; Johnson, K.; Sinha, A. Synoptic and mesoscale controls on the isotopic composition of precipitation in the western United States. Clim. Dyn. 2011, 38, 433-454. [CrossRef]

34. Buenning, N.H.; Stott, L.; Yoshimura, K.; Berkelhammer, M. The cause of the seasonal variation in the oxygen isotopic composition of precipitation along the western U.S. coast. J. Geophys. Res. D Atmos. 2012, 117. [CrossRef]

35. Buenning, N.; Stott, L.; Kanner, L.; Yoshimura, K. Diagnosing Atmospheric Influences on the Interannual 18O/16O Variations in Western U.S. Precipitation. Water 2013, 5, 1116-1140. [CrossRef]

36. Sharp, Z. Principles of Stable Isotope Geochemistry; Pearson Prentice Hall: Upper Saddle River, NJ, USA, 2007; $344 \mathrm{p}$.

37. Wright, W.E.; Long, A.; Comrie, A.C.; Leavitt, S.W.; Cavazos, T.; Eastoe, C. Monsoonal moisture sources revealed using temperature, precipitation, and precipitation stable isotope timeseries. Geophys. Res. Lett. 2001, 28, 787-790. [CrossRef]

38. Palmer, M.V.; Palmer, A.N. Petrographic and isotopic evidence for late-stage processes in sulfuric acid caves of the Guadalupe Mountains, New Mexico, USA. Int. J. Speleol. 2012, 41, 10. [CrossRef]

39. Winograd, I.J.; Riggs, A.C.; Coplen, T.B. The relative contributions of summer and cool-season precipitation to groundwater recharge, Spring Mountains, Nevada, USA. Hydrogeol. J. 1998, 6, 77-93. [CrossRef]

40. Wagner, J.D.M.; Cole, J.E.; Beck, J.W.; Patchett, P.J.; Henderson, G.M.; Barnett, H.R. Moisture variability in the southwestern United States linked to abrupt glacial climate change. Nat. Geosci. 2010, 3, 110-113. [CrossRef]

41. Pape, J.R.; Banner, J.L.; Mack, L.E.; Musgrove, M.; Guilfoyle, A. Controls on oxygen isotope variability in precipitation and cave drip waters, central Texas, USA. J. Hydrol. 2010, 385, 203-215. [CrossRef]

42. Ersek, V.; Clark, P.U.; Mix, A.C.; Cheng, H.; Edwards, R.L. Holocene winter climate variability in mid-latitude western North America. Nat. Commun. 2012, 3, 1219. [CrossRef] [PubMed]

43. Oster, J.L.; Montañez, I.P.; Sharp, W.D.; Cooper, K.M. Late Pleistocene California droughts during deglaciation and Arctic warming. Earth Planet. Sci. Lett. 2009, 288, 434-443. [CrossRef]

44. Oster, J.L.; Sharp, W.D.; Covey, A.K.; Gibson, J.; Rogers, B.; Mix, H. Climate response to the 8.2 ka event in coastal California. Sci. Rep. 2017, 7, 3886. [CrossRef] [PubMed]

45. Oster, J.L.; Montañez, I.P.; Santare, L.R.; Sharp, W.D.; Wong, C.; Cooper, K.M. Stalagmite records of hydroclimate in central California during termination 1. Quat. Sci. Rev. 2015, 127, 199-214. [CrossRef]

46. Mccabe-Glynn, S.E.; Johnson, K.R.; Berkelhammer, M.B.; Sinha, A.; Cheng, H.; Edwards, L. Pacific ocean sea surface temperature influence on southwestern United States climate during the past millennium: New evidence from a well-calibrated, high-resolution stalagmite $\delta^{18} \mathrm{O}$ record from the Sierra Nevada, California. Quat. Int. 2013, 310, 236-237. [CrossRef]

47. Lachniet, M.S.; Denniston, R.F.; Asmerom, Y.; Polyak, V.J. Orbital control of western North America atmospheric circulation and climate over two glacial cycles. Nat. Commun. 2014, 5, 3805. [CrossRef] [PubMed]

48. Lachniet, M.S. Chapter 20-A Speleothem Record of Great Basin Paleoclimate: The Leviathan Chronology, Nevada. In Developments in Earth Surface Processes; Oviatt, C.G., Shroder, J.F., Eds.; Elsevier: Amsterdam, The Netherlands, 2016; Volume 20, pp. 551-569.

49. Lora, J.M.; Mitchell, J.L.; Risi, C.; Tripati, A.E. North Pacific atmospheric rivers and their influence on western North America at the Last Glacial Maximum. Geophys. Res. Lett. 2017, 44, 1051-1059. [CrossRef]

50. Bhattacharya, T.; Tierney, J.E.; Addison, J.A.; Murray, J.W. Ice-sheet modulation of deglacial North American monsoon intensification. Nat. Geosci. 2018, 11, 848-852. [CrossRef]

51. Bartlein, P.J.; Anderson, K.H.; Anderson, P.M.; Edwards, M.E.; Mock, C.J.; Thompson, R.S.; Webb, R.S.; Webb, T., III; Whitlock, C. Paleoclimate simulations for North America over the past 21,000 years: Features of the simulated climate and comparisons with paleoenvironmental data. Quat. Sci. Rev. 1998, 17, 549-585. [CrossRef] 
52. Roy, P.D.; Rivero-Navarrete, A.; Sánchez-Zavala, J.L. Atlantic Ocean modulated hydroclimate of the subtropical northeastern Mexico since the last glacial maximum and comparison with the southern US. Earth Planet. Sci. Lett. 2016, 434, 141-150. [CrossRef]

53. McGee, D.; Donohoe, A.; Marshall, J.; Ferreira, D. Changes in ITCZ location and cross-equatorial heat transport at the Last Glacial Maximum, Heinrich Stadial 1, and the mid-Holocene. Earth Planet. Sci. Lett. 2014, 390, 69-79. [CrossRef]

54. Harvey, F.E.; Welker, J.M. Stable isotopic composition of precipitation in the semi-arid north-central portion of the US Great Plains. J. Hydrol. 2000, 238, 90-109. [CrossRef]

55. Aharon, P.; Dhungana, R. Ocean-atmosphere interactions as drivers of mid-to-late Holocene rapid climate changes: Evidence from high-resolution stalagmite records at DeSoto Caverns, Southeast USA. Quat. Sci. Rev. 2017, 170, 69-81. [CrossRef]

56. Liu, Z.; Bowen, G.J.; Welker, J.M. Atmospheric circulation is reflected in precipitation isotope gradients over the conterminous United States. J. Geophys. Res. 2010, 115. [CrossRef]

57. Gat, J.R.; Bowser, C.J.; Kendall, C. The contribution of evaporation from the Great Lakes to the continental atmosphere: Estimate based on stable isotope data. Geophys. Res. Lett. 1994, 21, 557-560. [CrossRef]

58. Burnett, A.W.; Kirby, M.E.; Mullins, H.T.; Patterson, W.P. Increasing Great Lake-Effect Snowfall during the Twentieth Century: A Regional Response to Global Warming? J. Clim. 2003, 16, 3535-3542. [CrossRef]

59. Machavaram, M.V.; Krishnamurthy, R.V. Earth surface evaporative process: A case study from the Great Lakes region of the United States based on deuterium excess in precipitation. Geochim. Cosmochim. Acta 1995, 59, 4279-4283. [CrossRef]

60. Dorale, J.A.; González, L.A.; Reagan, M.K.; Pickett, D.A.; Murrell, M.T.; Baker, R.G. A high-resolution record of Holocene climate change in speleothem calcite from cold water cave, Northeast Iowa. Science 1992, 258, 1626-1630. [CrossRef]

61. Dorale, J.A.; Edwards, R.L.; Ito, E.; Gonzalez, L.A. Climate and vegetation history of the midcontinent from 75 to 25 ka: A speleothem record from crevice cave, Missouri, USA. Science 1998, 282, 1871-1874. [CrossRef]

62. Sjostrom, D.J.; Welker, J.M. The influence of air mass source on the seasonal isotopic composition of precipitation, eastern USA. J. Geochem. Explor. 2009, 102, 103-112. [CrossRef]

63. Tian, C.; Wang, L.; Kaseke, K.F.; Bird, B.W. Stable isotope compositions $\left(\delta^{2} \mathrm{H}, \delta^{18} \mathrm{O}\right.$ and $\left.\delta^{17} \mathrm{O}\right)$ of rainfall and snowfall in the central United States. Sci. Rep. 2018, 8, 6712. [CrossRef] [PubMed]

64. Good, S.P.; Mallia, D.V.; Lin, J.C.; Bowen, G.J. Stable isotope analysis of precipitation samples obtained via crowdsourcing reveals the spatiotemporal evolution of Superstorm Sandy. PLoS ONE 2014, 9, e91117. [CrossRef] [PubMed]

65. Lawrence, R.J.; Gedzelman, D.S. Low stable isotope ratios of tropical cyclone rains. Geophys. Res. Lett. 1996, 23, 527-530. [CrossRef]

66. Price, R.M.; Swart, P.K.; Willoughby, H.E. Seasonal and spatial variation in the stable isotopic composition $\left(\delta^{18} \mathrm{O}\right.$ and $\left.\delta \mathrm{D}\right)$ of precipitation in south Florida. J. Hydrol. 2008, 358, 193-205. [CrossRef]

67. Hardt, B.; Rowe, H.D.; Springer, G.S.; Cheng, H.; Edwards, R.L. The seasonality of east central North American precipitation based on three coeval Holocene speleothems from southern West Virginia. Earth Planet. Sci. Lett. 2010, 295, 342-348. [CrossRef]

68. Springer, G.S.; Poston, H.A.; Hardt, B. Groundwater lowering and stream incision rates in the Central Appalachian Mountains of West Virginia, USA. J. Speleol. 2014, 44, 99-105. [CrossRef]

69. Giannini, A.; Kushnir, Y.; Cane, M.A. Interannual Variability of Caribbean Rainfall, ENSO, and the Atlantic Ocean*. J. Clim. 2000, 13, 297-311. [CrossRef]

70. Taylor, M.A.; Alfaro, E.J. Central America and the Caribbean, Climate of. In Encyclopedia of World Climatology; Encyclopedia of Earth Sciences Series; Springer: Dordrecht, The Netherlands, 2005; pp. 183-189.

71. Schneider, T.; Bischoff, T.; Haug, G.H. Migrations and dynamics of the intertropical convergence zone. Nature 2014, 513, 45-53. [CrossRef] [PubMed]

72. Waliser, D.E.; Gautier, C. A Satellite-derived Climatology of the ITCZ. J. Clim. 1993, 6, 2162-2174. [CrossRef]

73. Poveda, G.; Waylen, P.R.; Pulwarty, R.S. Annual and inter-annual variability of the present climate in northern South America and southern Mesoamerica. Palaeogeogr. Palaeoclimatol. Palaeoecol. 2006, 234, 3-27. [CrossRef]

74. Philander, S.G.H.; Gu, D.; Lambert, G.; Li, T.; Halpern, D.; Lau, N.-C.; Pacanowski, R.C. Why the ITCZ Is Mostly North of the Equator. J. Clim. 1996, 9, 2958-2972. [CrossRef] 
75. Amador, J.A. The Intra-Americas Sea Low-level Jet. Ann. N. Y. Acad. Sci. 2008, 1146, 153-188. [CrossRef] [PubMed]

76. Mestas-Nuñez, A.M.; Enfield, D.B.; Zhang, C. Water Vapor Fluxes over the Intra-Americas Sea: Seasonal and Interannual Variability and Associations with Rainfall. J. Clim. 2007, 20, 1910-1922. [CrossRef]

77. Hodell, D.A.; Anselmetti, F.S.; Ariztegui, D.; Brenner, M.; Curtis, J.H.; Gilli, A.; Grzesik, D.A.; Guilderson, T.J.; Müller, A.D.; Bush, M.B. An 85-ka record of climate change in lowland Central America. Quat. Sci. Rev. 2008, 27, 1152-1165. [CrossRef]

78. George, R.K.; Waylen, P.; Laporte, S. Interannual variability of annual streamflow and the Southern Oscillation in Costa Rica. Hydrol. Sci. J. 1998, 43, 409-424. [CrossRef]

79. Magaña, V.O.; Vázquez, J.L.; Pérez, J.L.; Pérez, J.B. Impact of El Niño on precipitation in Mexico. Geofís. Int. 2003, 42, 313-330.

80. Lachniet, M.S.; Patterson, W.P. Oxygen isotope values of precipitation and surface waters in northern Central America (Belize and Guatemala) are dominated by temperature and amount effects. Earth Planet. Sci. Lett. 2009, 284, 435-446. [CrossRef]

81. Lachniet, M.S.; Patterson, W.P. Use of correlation and stepwise regression to evaluate physical controls on the stable isotope values of Panamanian rain and surface waters. J. Hydrol. 2006, 324, 115-140. [CrossRef]

82. Lachniet, M.S.; Patterson, W.P.; Burns, S.; Asmerom, Y.; Polyak, V. Caribbean and Pacific moisture sources on the Isthmus of Panama revealed from stalagmite and surface water $\delta^{18} \mathrm{O}$ gradients. Geophys. Res. Lett. 2007, 34, 149. [CrossRef]

83. Lachniet, M.S. Sea surface temperature control on the stable isotopic composition of rainfall in Panama. Geophys. Res. Lett. 2009, 36. [CrossRef]

84. Jones, I.C.; Banner, J.L.; Humphrey, J.D. Estimating recharge in a tropical Karst Aquifer. Water Resour. Res. 2000, 36, 1289-1299. [CrossRef]

85. Vieten, R.; Warken, S.; Winter, A.; Scholz, D.; Miller, T.; Spötl, C.; Schröder-Ritzrau, A. Monitoring of Cueva Larga, Puerto Rico-A First Step to Decode Speleothem Climate Records. In Karst Groundwater Contamination and Public Health; Advances in Karst Science; Springer: Cham, Switzerland, 2017; pp. 319-331.

86. Vieten, R.; Warken, S.; Winter, A.; Schröder-Ritzrau, A.; Scholz, D.; Spötl, C. Hurricane Impact on Seepage Water in Larga Cave, Puerto Rico. J. Geophys. Res. Biogeosci. 2018, 123, 879-888. [CrossRef]

87. Medina-Elizalde, M.; Burns, S.J.; Polanco-Martínez, J.M.; Beach, T.; Lases-Hernández, F.; Shen, C.-C.; Wang, H.-C. High-resolution speleothem record of precipitation from the Yucatan Peninsula spanning the Maya Preclassic Period. Glob. Planet. Chang. 2016, 138, 93-102. [CrossRef]

88. Lases-Hernandez, F.; Medina-Elizalde, M.; Burns, S.; DeCesare, M. Long-term monitoring of drip water and groundwater stable isotopic variability in the Yucatán Peninsula: Implications for recharge and speleothem rainfall reconstruction. Geochim. Cosmochim. Acta 2019, 246, 41-59. [CrossRef]

89. Sánchez-Murillo, R.; Durán-Quesada, A.M.; Birkel, C.; Esquivel-Hernández, G.; Boll, J. Tropical precipitation anomalies and d-excess evolution during El Niño 2014-16. Hydrol. Process. 2017, 31, 956-967. [CrossRef]

90. Vuille, M. Modeling $\delta^{18} \mathrm{O}$ in precipitation over the tropical Americas: 1 . Interannual variability and climatic controls. J. Geophys. Res. 2003, 108. [CrossRef]

91. Arienzo, M.M.; Swart, P.K.; Pourmand, A.; Broad, K.; Clement, A.C.; Murphy, L.N.; Vonhof, H.B.; Kakuk, B. Bahamian speleothem reveals temperature decrease associated with Heinrich stadials. Earth Planet. Sci. Lett. 2015, 430, 377-386. [CrossRef]

92. Arienzo, M.M.; Swart, P.K.; Broad, K.; Clement, A.C.; Pourmand, A.; Kakuk, B. Multi-proxy evidence of millennial climate variability from multiple Bahamian speleothems. Quat. Sci. Rev. 2017, 161, 18-29. [CrossRef]

93. Medina-Elizalde, M.; Burns, S.J.; Lea, D.W.; Asmerom, Y.; von Gunten, L.; Polyak, V.; Vuille, M.; Karmalkar, A. High resolution stalagmite climate record from the Yucatán Peninsula spanning the Maya terminal classic period. Earth Planet. Sci. Lett. 2010, 298, 255-262. [CrossRef]

94. Frappier, A.B.; Sahagian, D.; Carpenter, S.J.; González, L.A.; Frappier, B.R. Stalagmite stable isotope record of recent tropical cyclone events. Geology 2007, 35, 111-114. [CrossRef]

95. Lachniet, M.S.; Johnson, L.; Asmerom, Y.; Burns, S.J.; Polyak, V.; Patterson, W.P.; Burt, L.; Azouz, A. Late Quaternary moisture export across Central America and to Greenland: Evidence for tropical rainfall variability from Costa Rican stalagmites. Quat. Sci. Rev. 2009, 28, 3348-3360. [CrossRef] 
96. Moseley, G.E.; Edwards, R.L.; Wendt, K.A.; Cheng, H.; Dublyansky, Y.; Lu, Y.; Boch, R.; Spötl, C. Reconciliation of the Devils Hole climate record with orbital forcing. Science 2016, 351, 165-168. [CrossRef] [PubMed]

97. Rehfeld, K.; Münch, T.; Ho, S.L.; Laepple, T. Global patterns of declining temperature variability from the Last Glacial Maximum to the Holocene. Nature 2018, 554, 356-359. [CrossRef]

98. Wong, C.I.; Breecker, D.O. Advancements in the use of speleothems as climate archives. Quat. Sci. Rev. 2015, 127, 1-18. [CrossRef]

99. Lambert, W.J.; Aharon, P. Controls on dissolved inorganic carbon and $\delta^{13} \mathrm{C}$ in cave waters from DeSoto Caverns: Implications for speleothem $\delta^{13} \mathrm{C}$ assessments. Geochim. Cosmochim. Acta 2011, 75, 753-768. [CrossRef]

100. Mickler, P.J.; Banner, J.L.; Stern, L.; Asmerom, Y.; Edwards, R.L.; Ito, E. Stable isotope variations in modern tropical speleothems: Evaluating equilibrium vs. kinetic isotope effects 1. Geochim. Cosmochim. Acta 2004, 68, 4381-4393. [CrossRef]

101. Tremaine, D.M.; Froelich, P.N.; Wang, Y. Speleothem calcite farmed in situ: Modern calibration of $\delta^{18} \mathrm{O}$ and $\delta^{13} \mathrm{C}$ paleoclimate proxies in a continuously-monitored natural cave system. Geochim. Cosmochim. Acta 2011, 75, 4929-4950. [CrossRef]

102. Banner, J.L.; Guilfoyle, A.; James, E.W.; Stern, L.A.; Musgrove, M. Seasonal Variations in Modern Speleothem Calcite Growth in Central Texas, U.S.A. J. Sediment. Res. 2007, 77, 615-622. [CrossRef]

103. Wong, C.I.; Banner, J.L.; Musgrove, M. Seasonal dripwater Mg/Ca and Sr/Ca variations driven by cave ventilation: Implications for and modeling of speleothem paleoclimate records. Geochim. Cosmochim. Acta 2011, 75, 3514-3529. [CrossRef]

104. Meyer, K.W.; Feng, W.; Breecker, D.O.; Banner, J.L.; Guilfoyle, A. Interpretation of speleothem calcite $\delta^{13} \mathrm{C}$ variations: Evidence from monitoring soil $\mathrm{CO}_{2}$, drip water, and modern speleothem calcite in central Texas. Geochim. Cosmochim. Acta 2014, 142, 281-298. [CrossRef]

105. Daëron, M.; Guo, W.; Eiler, J.; Genty, D.; Blamart, D.; Boch, R.; Drysdale, R.; Maire, R.; Wainer, K.; Zanchetta, G. ${ }^{13} \mathrm{C}^{18} \mathrm{O}$ clumping in speleothems: Observations from natural caves and precipitation experiments. Geochim. Cosmochim. Acta 2011, 75, 3303-3317. [CrossRef]

106. Feng, W.; Banner, J.L.; Guilfoyle, A.L.; Musgrove, M.; James, E.W. Oxygen isotopic fractionation between drip water and speleothem calcite: A 10-year monitoring study, central Texas, USA. Chem. Geol. 2012, 304-305, 53-67. [CrossRef]

107. Rehfeld, K.; Kurths, J. Similarity estimators for irregular and age-uncertain time series. Clim. Past 2014, 10, 107-122. [CrossRef]

108. Epskamp, S.; Cramer, A.; Waldorp, L.; Schmittmann, V.; Borsboom, D. qgraph: Network Visualizations of Relationships in Psychometric Data. J. Stat. Softw. 2012, 48, 1-18. [CrossRef]

109. Dansgaard, W.; Johnsen, S.J.; Clausen, H.B.; Dahl-Jensen, D.; Gundestrup, N.; Hammer, C.U.; Oeschger, H. North Atlantic climatic oscillations revealed by deep Greenland ice cores. In Climate Processes and Climate Sensitivity; Hansen, J.E., Takahashi, T., Eds.; Geophysical Monograph Series; American Geophysical Union: Washington, DC, USA, 1984; Volume 29, pp. 288-298. ISBN 9780875904047.

110. Oster, J.L.; Montañez, I.P.; Mertz-Kraus, R.; Sharp, W.D.; Stock, G.M.; Spero, H.J.; Tinsley, J.; Zachos, J.C. Millennial-scale variations in western Sierra Nevada precipitation during the last glacial cycle MIS 4/3 transition. Quat. Res. 2014, 82, 236-248. [CrossRef]

111. Shakun, J.D.; Burns, S.J.; Clark, P.U.; Cheng, H.; Edwards, R.L. Milankovitch-paced Termination II in a Nevada speleothem? Geophys. Res. Lett. 2011, 38, L18701. [CrossRef]

112. Springer, G.S.; Rowe, H.D.; Hardt, B.; Cheng, H.; Edwards, R.L. East central North America climates during marine isotope stages 3-5. Geophys. Res. Lett. 2014, 41, 3233-3237. [CrossRef]

113. Berger, A. Long-Term Variations of Daily Insolation and Quaternary Climatic Changes. J. Atmos. Sci. 1978, 35, 2362-2367. [CrossRef]

114. Winograd, I.J.; Coplen, T.B.; Landwehr, J.M.; Riggs, A.C.; Ludwig, K.R.; Szabo, B.J.; Kolesar, P.T.; Revesz, K.M. Continuous 500,000-year climate record from vein calcite in Devils hole, Nevada. Science 1992, 258, 255-260. [CrossRef] [PubMed]

115. Seierstad, I.K.; Abbott, P.M.; Bigler, M.; Blunier, T.; Bourne, A.J.; Brook, E.; Buchardt, S.L.; Buizert, C.; Clausen, H.B.; Cook, E.; et al. Consistently dated records from the Greenland GRIP, GISP2 and NGRIP ice cores for the past 104 ka reveal regional millennial-scale $\delta^{18} \mathrm{O}$ gradients with possible Heinrich event imprint. Quat. Sci. Rev. 2014, 106, 29-46. [CrossRef] 
116. Lachniet, M.S.; Asmerom, Y.; Bernal, J.P.; Polyak, V.J.; Vazquez-Selem, L. Orbital pacing and ocean circulation-induced collapses of the Mesoamerican monsoon over the past 22,000 y. Proc. Natl. Acad. Sci. USA 2013, 110, 9255-9260. [CrossRef] [PubMed]

117. Broccoli, A.J.; Dahl, K.A.; Stouffer, R.J. Response of the ITCZ to Northern Hemisphere cooling. Geophys. Res. Lett. 2006, 33. [CrossRef]

118. Schmidt, M.W.; Spero, H.J. Meridional shifts in the marine ITCZ and the tropical hydrologic cycle over the last three glacial cycles. Paleoceanogr. Paleoclimatol. 2011, 26. [CrossRef]

119. Wang, X.; Auler, A.S.; Edwards, R.L.; Cheng, H.; Ito, E.; Wang, Y.; Kong, X.; Solheid, M. Millennial-scale precipitation changes in southern Brazil over the past 90,000 years. Geophys. Res. Lett. 2007, 34. [CrossRef]

120. Singarayer, J.S.; Valdes, P.J.; Roberts, W.H.G. Ocean dominated expansion and contraction of the late Quaternary tropical rainbelt. Sci. Rep. 2017, 7, 9382. [CrossRef] [PubMed]

121. Munroe, J.S.; Laabs, B.J.C. Temporal correspondence between pluvial lake highstands in the southwestern US and Heinrich Event 1. J. Quat. Sci. 2013, 28, 49-58. [CrossRef]

122. Ibarra, D.E.; Egger, A.E.; Weaver, K.L.; Harris, C.R.; Maher, K. Rise and fall of late Pleistocene pluvial lakes in response to reduced evaporation and precipitation: Evidence from Lake Surprise, California. GSA Bull. 2014, 126, 1387-1415. [CrossRef]

123. McGee, D.; Moreno-Chamarro, E.; Green, B.; Marshall, J.; Galbraith, E.; Bradtmiller, L. Hemispherically asymmetric trade wind changes as signatures of past ITCZ shifts. Quat. Sci. Rev. 2018, 180, 214-228. [CrossRef]

124. Lachniet, M.S.; Asmerom, Y.; Polyak, V. Deglacial paleoclimate in the southwestern United States: An abrupt $18.6 \mathrm{ka}$ cold event and evidence for a North Atlantic forcing of Termination I. Quat. Sci. Rev. 2011, 30, 3803-3811. [CrossRef]

125. Broecker, W.; Putnam, A.E. How did the hydrologic cycle respond to the two-phase mystery interval? Quat. Sci. Rev. 2012, 57, 17-25. [CrossRef]

126. Wong, C.I.; Potter, G.L.; Montañez, I.P.; Otto-Bliesner, B.L.; Behling, P.; Oster, J.L. Evolution of moisture transport to the western US during the last deglaciation. Geophys. Res. Lett. 2016, 43, 3468-3477. [CrossRef]

127. Hermann, N.W.; Oster, J.L.; Ibarra, D.E. Spatial patterns and driving mechanisms of mid-Holocene hydroclimate in western North America. J. Quat. Sci. 2018, 33, 421-434. [CrossRef]

128. Bernal, J.P.; Lachniet, M.; McCulloch, M.; Mortimer, G.; Morales, P.; Cienfuegos, E. A speleothem record of Holocene climate variability from southwestern Mexico. Quat. Res. 2011, 75, 104-113. [CrossRef]

129. Winter, A.; Miller, T.; Kushnir, Y.; Sinha, A.; Timmermann, A.; Jury, M.R.; Gallup, C.; Cheng, H.; Edwards, R.L. Evidence for 800 years of North Atlantic multi-decadal variability from a Puerto Rican speleothem. Earth Planet. Sci. Lett. 2011, 308, 23-28. [CrossRef]

130. Lachniet, M.S.; Asmerom, Y.; Polyak, V.; Bernal, J.P. Two millennia of Mesoamerican monsoon variability driven by Pacific and Atlantic synergistic forcing. Quat. Sci. Rev. 2017, 155, 100-113. [CrossRef]

131. Webster, J.W.; Brook, G.A.; Railsback, L.B.; Cheng, H.; Edwards, R.L.; Alexander, C.; Reeder, P.P. Stalagmite evidence from Belize indicating significant droughts at the time of Preclassic Abandonment, the Maya Hiatus, and the Classic Maya collapse. Palaeogeogr. Palaeoclimatol. Palaeoecol. 2007, 250, 1-17. [CrossRef]

132. Wang, X.; Auler, A.S.; Edwards, R.L.; Cheng, H.; Ito, E.; Solheid, M. Interhemispheric anti-phasing of rainfall during the last glacial period. Quat. Sci. Rev. 2006, 25, 3391-3403. [CrossRef]

133. Arbuszewski, J.A.; deMenocal, P.B.; Cléroux, C.; Bradtmiller, L.; Mix, A. Meridional shifts of the Atlantic intertropical convergence zone since the Last Glacial Maximum. Nat. Geosci. 2013, 6, 959-962. [CrossRef]

134. Wang, P.X.; Wang, B.; Cheng, H.; Fasullo, J.; Guo, Z.T.; Kiefer, T.; Liu, Z.Y. The global monsoon across timescales: Coherent variability of regional monsoons. Clim. Past 2014, 10, 2007-2052. [CrossRef]

135. Cruz, F.W., Jr.; Burns, S.J.; Karmann, I.; Sharp, W.D.; Vuille, M.; Cardoso, A.O.; Ferrari, J.A.; Dias, P.L.S.; Viana, O. Insolation-driven changes in atmospheric circulation over the past 116,000 years in subtropical Brazil. Nature 2005, 434, 63-66. [CrossRef]

136. Sachs, J.P.; Sachse, D.; Smittenberg, R.H.; Zhang, Z.; Battisti, D.S.; Golubic, S. Southward movement of the Pacific intertropical convergence zone AD 1400-1850. Nat. Geosci. 2009, 2, 519-525. [CrossRef]

137. Collins, J.A.; Schefuß, E.; Heslop, D.; Mulitza, S.; Prange, M.; Zabel, M.; Tjallingii, R.; Dokken, T.M.; Huang, E.; Mackensen, A.; et al. Interhemispheric symmetry of the tropical African rainbelt over the past 23,000 years. Nat. Geosci. 2010, 4, 42-45. [CrossRef] 
138. Denniston, R.F.; Ummenhofer, C.C.; Wanamaker, A.D.; Lachniet, M.S.; Villarini, G.; Asmerom, Y.; Polyak, V.J.; Passaro, K.J.; Cugley, J.; Woods, D.; et al. Expansion and Contraction of the Indo-Pacific Tropical Rain Belt over the Last Three Millennia. Sci. Rep. 2016, 6, 34485. [CrossRef] [PubMed]

139. Yan, H.; Wei, W.; Soon, W.; An, Z.; Zhou, W.; Liu, Z.; Wang, Y.; Carter, R.M. Dynamics of the intertropical convergence zone over the western Pacific during the Little Ice Age. Nat. Geosci. 2015, 8, 315-320. [CrossRef]

140. Ridley, H.E.; Asmerom, Y.; Baldini, J.U.L.; Breitenbach, S.F.M.; Aquino, V.V.; Prufer, K.M.; Culleton, B.J.; Polyak, V.; Lechleitner, F.A.; Kennett, D.J.; et al. Aerosol forcing of the position of the intertropical convergence zone since ad 1550. Nat. Geosci. 2015, 8, 195-200. [CrossRef]

141. Winter, A.; Zanchettin, D.; Miller, T.; Kushnir, Y.; Black, D.; Lohmann, G.; Burnett, A.; Haug, G.H.; Estrella-Martínez, J.; Breitenbach, S.F.M.; et al. Persistent drying in the tropics linked to natural forcing. Nat. Commun. 2015, 6, 7627. [CrossRef] [PubMed]

142. Zanchettin, D.; Timmreck, C.; Graf, H.-F.; Rubino, A.; Lorenz, S.; Lohmann, K.; Krüger, K.; Jungclaus, J.H. Bi-decadal variability excited in the coupled ocean-atmosphere system by strong tropical volcanic eruptions. Clim. Dyn. 2012, 39, 419-444. [CrossRef]

143. Lachniet, M.S. Are aragonite stalagmites reliable paleoclimate proxies? Tests for oxygen isotope time-series replication and equilibrium. GSA Bull. 2015, 127, 1521-1533. [CrossRef]

144. Dorale, J.A.; Liu, Z. Limitations of Hendy test criteria in judging the paleoclimatic suitability of speleothems and the need for replication. J. Cave Karst Stud. 2009, 71, 73-80.

145. Aharon, P.; Aldridge, D.; Hellstrom, J. Rainfall Variability and the Rise and Collapse of the Mississippian Chiefdoms: Evidence from a Desoto Caverns Stalagmite: Giosan/Climates, Landscapes, and Civilizations. In Climates, Landscapes, and Civilizations; Giosan, L., Fuller, D.Q., Nicoll, K., Flad, R.K., Clift, P.D., Eds.; Geophysical Monograph Series; American Geophysical Union: Washington, DC, USA, 2012; pp. 35-42, ISBN 9781118704325.

146. Pollock, A.L.; van Beynen, P.E.; DeLong, K.L.; Polyak, V.; Asmerom, Y. A speleothem-based mid-Holocene precipitation reconstruction for West-Central Florida. Holocene 2017, 27, 987-996. [CrossRef]

147. Polyak, V.J.; Asmerom, Y.; Burns, S.J.; Lachniet, M.S. Climatic backdrop to the terminal Pleistocene extinction of North American mammals. Geology 2012, 40, 1023-1026. [CrossRef]

148. Denniston, R.F.; González, L.A.; Asmerom, Y.; Baker, R.G.; Reagan, M.K.; Arthur Bettis, E. Evidence for increased cool season moisture during the middle Holocene. Geology 1999, 27, 815-818. [CrossRef]

149. Denniston, R.F.; DuPree, M.; Dorale, J.A.; Asmerom, Y.; Polyak, V.J.; Carpenter, S.J. Episodes of late Holocene aridity recorded by stalagmites from Devil's icebox Cave, Central Missouri, USA. Quat. Res. 2007, 68, 45-52. [CrossRef]

150. Lundeen, Z.; Brunelle, A.; Burns, S.J.; Polyak, V.; Asmerom, Y. A speleothem record of Holocene paleoclimate from the northern Wasatch Mountains, southeast Idaho, USA. Quat. Int. 2013, 310, 83-95. [CrossRef]

151. Pollock, A.L.; van Beynen, P.E.; DeLong, K.L.; Polyak, V.; Asmerom, Y.; Reeder, P.P. A mid-Holocene paleoprecipitation record from Belize. Palaeogeogr. Palaeoclimatol. Palaeoecol. 2016, 463, 103-111. [CrossRef]

152. Denniston, R.F.; Asmerom, Y.; Polyak, V.; Dorale, J.A.; Carpenter, S.J.; Trodick, C.; Hoye, B.; González, L.A. Synchronous millennial-scale climatic changes in the Great Basin and the North Atlantic during the last interglacial. Geology 2007, 35, 619-622. [CrossRef]

153. Marshall, D.; Ghaleb, B.; Countess, R.; Gabities, J. Preliminary paleoclimate reconstruction based on a 12,500 year old speleothem from Vancouver Island, Canada: Stable isotopes and U-Th disequilibrium dating. Quat. Sci. Rev. 2009, 28, 2507-2513. [CrossRef]

154. Mangini, A.; Blumbach, P.; Verdes, P.; Spötl, C.; Scholz, D.; Machel, H.; Mahon, S. Combined records from a stalagmite from Barbados and from lake sediments in Haiti reveal variable seasonality in the Caribbean between 6.7 and 3 ka BP. Quat. Sci. Rev. 2007, 26, 1332-1343. [CrossRef]

155. Fensterer, C.; Scholz, D.; Hoffmann, D.; Spötl, C.; Pajón, J.M.; Mangini, A. Cuban stalagmite suggests relationship between Caribbean precipitation and the Atlantic Multidecadal Oscillation during the past $1.3 \mathrm{ka}$. Holocene 2012, 22, 1405-1412. [CrossRef]

156. Fensterer, C.; Scholz, D.; Hoffmann, D.L.; Spötl, C.; Schröder-Ritzrau, A.; Horn, C.; Pajón, J.M.; Mangini, A. Millennial-scale climate variability during the last $12.5 \mathrm{ka}$ recorded in a Caribbean speleothem. Earth Planet. Sci. Lett. 2013, 361, 143-151. [CrossRef] 
157. Stinnesbeck, W.; Becker, J.; Hering, F.; Frey, E.; González, A.G.; Fohlmeister, J.; Stinnesbeck, S.; Frank, N.; Terrazas Mata, A.; Benavente, M.E.; et al. The earliest settlers of Mesoamerica date back to the late Pleistocene. PLoS ONE 2017, 12, e0183345. [CrossRef] [PubMed]

158. Asmerom, Y.; Polyak, V.J.; Rasmussen, J.B.T.; Burns, S.J.; Lachniet, M. Multidecadal to multicentury scale collapses of Northern Hemisphere monsoons over the past millennium. Proc. Natl. Acad. Sci. USA 2013, 110, 9651-9656. [CrossRef] [PubMed]

159. McCabe-Glynn, S.; Johnson, K.R.; Strong, C.; Berkelhammer, M.; Sinha, A.; Cheng, H.; Edwards, R.L. Variable North Pacific influence on drought in southwestern North America since AD 854. Nat. Geosci. 2013, 6, 617-621. [CrossRef]

160. Denniston, R.F.; González, L.A.; Asmerom, Y.; Reagan, M.K.; Recelli-Snyder, H. Speleothem carbon isotopic records of Holocene environments in the Ozark Highlands, USA. Quat. Int. 2000, 67, 21-27. [CrossRef]

161. Denniston, R.F.; González, L.A.; Baker, R.G.; Asmerom, Y.; Reagan, M.K.; Edwards, R.L.; Alexander, E.C. Speleothem evidence for Holocene fluctuations of the prairie-forest ecotone, north-central USA. Holocene 1999, 9, 671-676. [CrossRef]

162. Denniston, R.F.; Gonzalez, L.A.; Asmerom, Y.; Polyak, V.; Reagan, M.K.; Saltzman, M.R. A high-resolution speleothem record of climatic variability at the Allerød-Younger Dryas transition in Missouri, central United States. Palaeogeogr. Palaeoclimatol. Palaeoecol. 2001, 176, 147-155. [CrossRef]

163. Lachniet, M.S.; Asmerom, Y.; Burns, S.J.; Patterson, W.P.; Polyak, V.J.; Seltzer, G.O. Tropical response to the 8200 yr B.P. cold event? Speleothem isotopes indicate a weakened early Holocene monsoon in Costa Rica. Geology 2004, 32, 957-960. [CrossRef]

164. Rivera-Collazo, I.; Winter, A.; Scholz, D.; Mangini, A.; Miller, T.; Kushnir, Y.; Black, D. Human adaptation strategies to abrupt climate change in Puerto Rico ca. $3.5 \mathrm{ka}$. Holocene 2015, 25, 627-640. [CrossRef]

165. Asmerom, Y.; Polyak, V.; Burns, S.; Rassmussen, J. Solar forcing of Holocene climate: New insights from a speleothem record, southwestern United States. Geology 2007, 35, 1-4. [CrossRef]

(C) 2019 by the authors. Licensee MDPI, Basel, Switzerland. This article is an open access article distributed under the terms and conditions of the Creative Commons Attribution (CC BY) license (http:/ / creativecommons.org/licenses/by/4.0/). 